\title{
Barriers to obstetric fistula treatment in low-income countries: A systematic review
}

\author{
Benjamin Bellows \\ Population Council \\ Rachel Bach \\ Zoe Baker \\ Charlotte E. Warren \\ Population Council
}

Follow this and additional works at: https://knowledgecommons.popcouncil.org/departments_sbsr-rh

Part of the Demography, Population, and Ecology Commons, Family, Life Course, and Society Commons, Gender and Sexuality Commons, International Public Health Commons, and the Maternal and Child Health Commons

How does access to this work benefit you? Let us know!

\section{Recommended Citation}

Bellows, Benjamin, Rachel Bach, Zoe Baker, and Charlotte E. Warren. 2014. "Barriers to obstetric fistula treatment in low-income countries: A systematic review." Nairobi: Population Council. Version of record: https://doi.org/10.1111/tmi.12893 


\section{BARRIERS TO OBSTEIRIC} FISTULA TREATMENT

\section{IN LOW-INCOME COUNTRIES:}

\section{A SYSTEMATIC REVIEW}


The Population Council confronts critical health and development issues-from stopping the spread of HIV to improving reproductive health and ensuring that young people lead full and productive lives. Through biomedical, social science, and public health research in 50 countries, we work with our partners to deliver solutions that lead to more effective policies, programs, and technologies that improve lives around the world. Established in 1952 and headquartered in New York, the Council is a nongovernmental, nonprofit organization governed by an international board of trustees.

Population Council

4301 Connecticut Avenue NW, \#280

Washington, DC 20008

USA

Tel: (202)-237-9400

Fax: (202)-237-8410

www.popcouncil.org

Suggested citation: Bellows, Ben, Rachel Bach, Zoe Baker, Charlotte Warren. 2015. Barriers to Obstetric Fistula Treatment in Low-income Countries: A Systematic Review. Nairobi: Population Council. 


\section{Table of Contents}

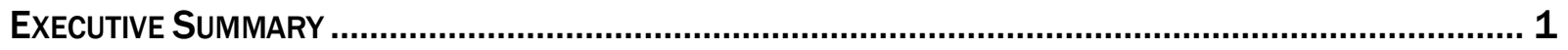

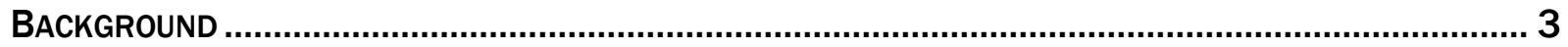

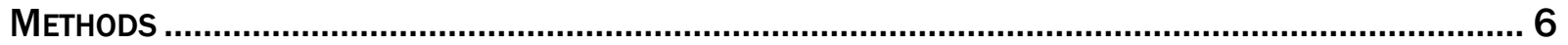

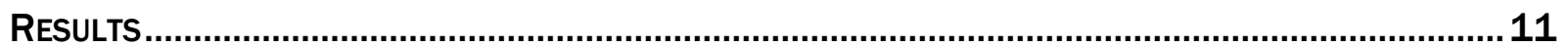

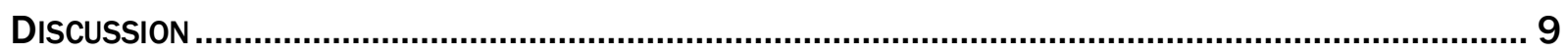

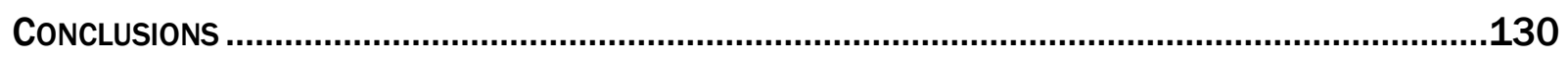

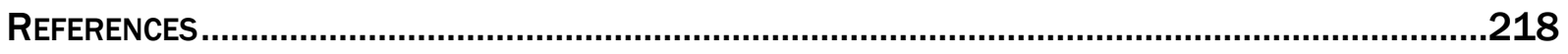




\section{Executive Summary}

\section{BACKGROUND}

Obstetric fistula is a maternal morbidity condition, which occurs in some low-income countries, caused by prolonged obstructed labor that results in a hole between the vagina and the bladder or rectum through which urine or feces leak. Unrepaired fistula can lead to lifelong ostracism, stigma, and shame.

Obstetric fistula is both preventable and treatable, but women in these countries experience delays in seeking repair due to a number of factors including awareness of their condition as well as the potential for treatment, resources necessary for seeking care, lack of skilled fistula surgeons, and long hospital waiting times.

UNFPA (2012) estimates that 2 to 3.5 million women are currently living with fistula worldwide, with at least 50,000 to 100,000 new cases occurring every year. The true number of women with fistula may actually be higher, as untreated patients who never reach a medical facility are more difficult for researchers to identify, and sampling biases are hard to verify.

This review aims to identify and understand the barriers affecting women's access to fistula repair, to inform the design of possible interventions that may be effective in addressing these barriers. This work may also identify research gaps surrounding fistula in low-income countries that require targeted formative research before interventions can be designed.

\section{METHODS}

A three-stage search protocol was developed using key terms to identify relevant papers. The first stage reviewed titles and abstracts identified from bibliographic databases as well as grey literature searches with explicit inclusion and exclusion criteria. In the second stage, full articles from the first phase were reviewed in parallel by two reviewers who then discussed any discrepancies and agreed on the standardization of the extracted data. The third stage included a qualitative review of references in key articles, expert inquiry, and data extraction from relevant sources. Papers that met the inclusion criteria included interviews, case studies, assessments, or reports that discussed at least one of the three delays in seeking care or an intervention that aimed to reduce the prevalence or incidence of fistula.

A total of 3,921 articles were identified in the electronic database search. Thirty were added from a review of the grey literature, and 21 from the expanded search. A total of 110 studies were included in the systematic review. 


\section{RESULTS}

The 110 articles were further categorized by nine barriers-psychosocial, cultural, awareness, social, financial, transportation, facility shortages, quality of care and politicalwhich correspond with Thaddeus and Maine's (1994) Three Delays Model. The articles were further categorized into five types: articles featuring barriers to treatment as their primary focus; articles identifying factors perceived as barriers; articles briefly mentioning barriers; reviews, needs assessments or annual reports; and articles focusing on interventions that aim to remove barriers to treatment. Interventions were analyzed in further detail to ascertain which barriers they targeted and their effectiveness during their study period.

\section{DISCUSSION}

From the articles included in this systematic review, it is consistently observed that obstetric fistula is directly linked to poverty, income inequality, gender disparities, discrimination, and poor education. Previous interventions may have achieved increased access to fistula treatment by removing the barriers preventing one or more of the three delays in seeking maternal healthcare. Community-based models identifying women who are disempowered and stigmatized can address the first barrier of limited awareness and knowledge. Transportation and healthcare financing models that successfully refer women with fistula to a surgical center are critical for overcoming the second barrier that prevents women from reaching a medical facility. Provider empathy and respectful care, strong surgical skills, and prioritized registration at facilities ensure that the third delay, appropriate care at a facility, is reduced for women seeking fistula repair services. The number of studies that evaluate interventions is low, however, and study outcomes vary, along with varying effect measurements between studies, making it impossible to aggregate results into a metaanalysis of the effect of interventions on treating women with fistula and removing the barriers to its care.

\section{CONCLUSIONS}

While barriers to fistula treatment may be easily identified, reducing their effects is difficult and requires sustained interventions that may target several barriers. There are few scientific studies of fistula prevalence and few studies of population-based strategies to improve fistula treatment. The results presented in this review identify current evidence gaps that must be addressed in research, for generating information for planning and implementing future interventions to improve access to fistula treatment in low-income regions. 


\section{Background}

\section{GOALS AND RATIONALE FOR CURRENT REVIEW}

Obstetric fistula is a maternal morbidity with devastating effects on a woman's life, persisting in low-income countries but virtually eliminated from the morbidity burden in highand middle-income countries. UNFPA (2012) estimates 2 to 3.5 million women currently suffer untreated fistula worldwide; and at least 50,000 to 100,000 women develop a fistula every year. There is uncertainty, however, about the prevalence estimate because of the rarity of diagnosis and a lack of high quality studies.

Because women living with fistula are predominantly poor, geographically and socially isolated, and with little political power, identifying these women for accurate prevalence or incidence data is difficult. A recent systematic review found an aggregate prevalence of 0.29 cases per 1,000 women of reproductive age and incidence of 0.09 new cases per 1,000 recently pregnant women each year, suggesting no more than one million women worldwide currently living with fistula (Adler et al. 2013). That study, however, likely missed women who never reached a hospital or who are isolated from their communities. The uncertainty in these estimates and difficulty in measuring the extent of the problem underscore the difficulties in mounting an effective response for fistula's treatment and prevention.

Obstetric fistula is both preventable and treatable. In recent years, various initiatives have been established to prevent and repair fistula but women experience delays in seeking repair due to a number of factors. Women with fistula may be unaware that repair is possible, or lack the resources to seek care, and may face delays in receiving appropriate treatment due to personnel or facility shortages and poor quality of care (Mukisa and Cole 2013, Obaid and Chong 2004, Bangser 2011, Fiander et al. 2013, Matsamura 2004).

This review aims to identify and understand the delays in receiving treatment and corresponding barriers to accessing fistula treatment, to document interventions that help to overcome barriers, and to specify gaps in the literature that require further research.

\section{DEFINING AND CONCEPTUALIZING OBSTETRIC FISTULA}

\section{What is Obstetric Fistula?}

The World Health Organization (2006) defines obstetric fistula as an "abnormal opening between a women's vagina and bladder and/or rectum through which her urine and/or feces continually leak." Pressure from a baby's head during prolonged or obstructed labor restricts blood flow and damages tissues between the vagina and the bladder or rectum. Although obstetric fistula is caused by prolonged and obstructed labor, it is rooted in poverty, predominantly affecting marginalized women who lack access to quality obstetric care, who typically are of lower socio-economic status, with lower levels of education, in rural areas, without prenatal care, and married at younger ages (Zheng and Anderson 2009). 
Childbirth care is affected by a variety of factors including access, socio-economic resources, and culture. Obstetric care may be geographically or financially unavailable, home delivery may be common and preferred over facilities, while timely referral systems for emergency obstetric care may be lacking, and girls and women may lack decision-making power and agency for seeking care. Many barriers preventing care for pregnant women and during labor are mirrored in women with fistula unable to access care. A poor, rural, pregnant woman may be unable to afford transportation for birth in a medical facility, and may be similarly unable to access transportation to a facility if she develops a fistula during delivery.

In addition to incontinence and other health problems with direct associations, fistula can lead to lifelong social and psychological problems involving ostracism, stigma, and shame (Blum 2012, Jones 2007, Yeakey et al. 2009). Women may be isolated from their family and community, divorced, or unable to work or participate in community events because of their condition. Community members may blame women living with fistula for their condition, viewing it as punishment for sin or a venereal disease or curse. Consequently, fistula is also associated with psychosocial problems such as depression and anxiety, which may further contribute to inability to seek treatment. Fistula is also associated with sexual, fertility, and future childbearing concerns (Yeakey et al. 2009, Wall et al. 2005, Arrowsmith et al. 1996).

Surgical treatment of fistula is generally reported to be successful, although there is limited long-term evaluation on urinary continence or subsequent quality of life (Creanga et al. 2007). In low-income countries, women have less access to appropriate surgical care for repair due to the low availability of health facilities with repair services and lack of surgical training for fistula repair. In addition to these supply side barriers to repair, a variety of demand side factors affect women's care seeking for fistula repair: great distances to health facilities, high cost of travel to facilities, and high costs of services. In addition, women may not be aware that treatment is available, or they may lack decision power and attitudes for seeking care. Furthermore, due to the large backlog of women requiring repair and limited available surgeons and personnel, women may experience long waits (Velez et al. 2007, Wall et al. 2005, Ramsey et al. 2007, Browning and Patel 2004).

\section{Conceptual Frameworks}

Thaddeus and Maine's (1994) Three Delays Model provides the theoretical context for understanding the barriers to accessing obstetric fistula care. Delay is understood as comprising three phases. Phase I is a delay in deciding to seek care by an individual, family, or both, and includes factors associated with decision making, women's status, illness characteristics, distances from facilities, financial and opportunity costs, previous health system experiences, and perceived quality of care. Phase II is delay in reaching an adequate care facility, with physical accessibility including facility distribution, travel time, availability and cost, and road conditions. Phase III comprises delay in receiving adequate care at a facility, including the adequacy of the referral system, and shortages of supplies, equipment, and trained personnel, as well as competence of available personnel. For this review, we adapted this model for delays to fistula treatment (Figure 1). 


\section{Figure 1: Three Delays Model to Fistula Treatment}

Factors Affecting

Utilization and Outcome
Phases of Delay

Phase I:

Deciding to Seek Care

Cultural

Awareness

Social

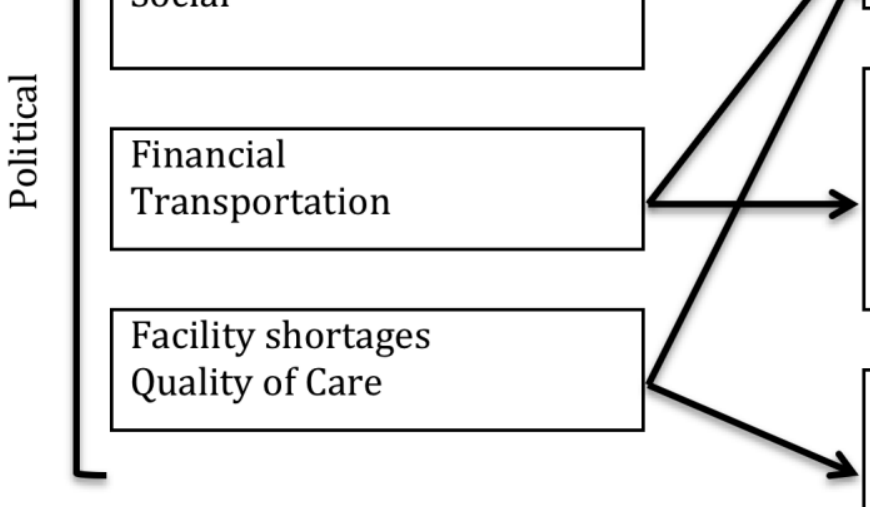

Phase II:

Identifying and

Reaching Medical

Facility

Phase III:

Receiving Adequate

and Appropriate

Treatment

\section{OBJECTIVES}

The primary objective of this systematic review is to identify and understand the barriers preventing women from accessing fistula repair at all three phases of delay, as presented by Thaddeus and Maine (1994), to inform the design of possible interventions that may be effective in addressing these barriers. This work may also identify gaps in knowledge that require targeted formative research before interventions can be designed. 


\section{Methods}

\section{IDENTIFYING AND DESCRIBING STUDIES}

\section{Search of Bibliographic Databases}

Bibliographic database searches used specified key terms to identify studies for potential inclusion in the review. Databases searched include: PubMed; POPLINE; ELDIS; InterScience (WILEY); ScienceDirect; Cochrane EPOC; World Health Organization Library Information System (WHOLIS); The Database of Abstracts of Reviews of Effectiveness; Web of Science; Library of Congress; Library, Information Science and Technology (LISTA); and Bioline International. Key terms used were:

“vaginal fistula" OR "vesicovaginal fistula" OR "rectovaginal fistula" OR "obstructed labor" OR "prolonged labor" OR "obstetric fistula"

AND

"treatment" OR “repair" OR "access to care" OR "poverty" OR “financial barrier*1" OR "transport*" OR “cultural barrier*” OR "economic barrier*”

Articles identified in database searches were imported to Mendeley for review.

\section{Phase I Inclusion and Exclusion Criteria}

In Phase I, abstracts of all studies identified in database searches were reviewed to determine whether they should be included, or excluded, in the next review phase. The following inclusion and exclusion criteria were utilized:

Topic: Articles were only included for further review if they discussed obstetric fistula and potential barriers to treatment. Articles focusing on fistula associated with other causes such as cancer, radiation, or Crohn's disease were excluded, as were articles not mentioning fistula. Articles exclusively discussing risk factors for developing fistula were also excluded. Articles were included if they discussed lack of high quality care, prevalence of fistula, treatment seeking for fistula, reasons for successful or unsuccessful treatment, need for multiple surgeries, cultural factors, or other issues that may be perceived as treatment barriers.

Language: To be included for further review, studies were required to be in English, or have an English abstract available.

Population: Only articles focusing on populations in low-income countries were included.

\footnotetext{
${ }^{1}$ Asterisk denotes inclusion of all "MeSH" terms during database searches
} 
Time frame: Only articles published from 1980 to the present were included for further review. 1980 was established as the terminal date to be as comprehensive as possible without focusing on studies that may include outdated information.

Type of study: Types of studies included for further review comprised case reports, comparative studies, journal articles, meta analyses, reviews, and systematic reviews.

\section{Search of Publishers' Pages}

After identifying studies from database searches, five publishers' pages of journals were individually searched for additional studies: International Journal of Gynecology and

Obstetrics, International Urogynecology Journal, British Journal of Obstetrics and Gynaecology, The Lancet, and Health Policy and Planning.

These journals were selected for further review based on a combination of a frequency of appearances in our database search and relatively high impact factors. Publishers' pages were searched using the same key terms used in the database searches.

\section{Search of Organization and Network Websites}

Several organizational and network websites were searched for additional studies or reports. Websites of interest were identified using Google searches of fistula campaigns and organizations, as well as expert recommendations.

Websites of EngenderHealth, Human Rights Watch, Fistula Care, Comprehensive Community Based Rehabilitation in Tanzania (CCBRT), Women's Dignity Project, United Nations Population Fund (UNFPA), Campaign to End Fistula, United States Agency for International Development (USAID), Department for International Development (DfID), Marie Stopes International, Population Council, Results for Development, World Health Organization (WHO), Worldwide Fistula Fund, and Fistula Foundation were included in this web search.

\section{Phase II Inclusion and Exclusion}

After identifying studies from bibliographic database searches, publishers' pages, and organization and network websites, we proceeded to Phase II with inclusion and exclusion criteria. Two researchers separately reviewed and included only articles that met our criteria. Articles were read in their entirety and included or excluded using the following criteria:

Barriers to treatment: Articles were excluded if there were no discussions of factors that may be perceived as barriers to obstetric fistula treatment.

Treatment delays: To be included in Phase II, articles were required to examine at least one outcome addressing one of the three delays to care presented by Thaddeus and Maine (1994) (delay in the decision to seek care, delay in arrival at a health facility, or delay in the provision of adequate care).

For each article included in Phase II, the researchers entered article information into a data extraction form (Appendix A) and saved each entry in an Excel spreadsheet. Data entered into the extraction form included information on the article's title, authors, publication date, 
journal or source, study design, country, length of study, population of interest, setting or sampling frame, comparison group (if applicable), intervention (if applicable), outcomes and barriers identified, and additional notes.

After their separate, parallel screenings of the articles, the two researchers discussed any discrepancies and made a final, collaborative judgment of inclusion or exclusion of the articles in question.

\section{Expert Recommendations}

Additional articles were sent from the International Research Advisory Group Meeting led by Fistula Care Plus in Boston in July 2014. Eleven articles were sent; four had already been identified in the electronic database search, resulting in seven additional expert recommendations. Of those seven resultant articles, four were duplicates already identified in the electronic database searches.

\section{French Database Search}

The same bibliographic databases searched in English were also searched in French, using the key terms:

"fistule vaginale" OR "lésions iatrogènes" OR "incontinence urinaire" OR "fistule vésicovaginale" OR "fistule recto-vaginale" OR "dystocia" OR "travail prolongé" OR “fistule obstétricale" OR "après traitement chirurgical"

AND

"traitement" OR "réparation" OR "accès aux soins" OR "barrière financière*" OR "pauvreté" OR "transport" OR "barrière culturelle*" OR "barrière économique*" OR "intégration sociale"

Due to the low number of French articles found using database searches, Phase II inclusion and exclusion criteria were immediately used to determine which articles to include in the review. 


\section{SEARCH RESULTS}

The search was conducted from June through July 2014. A total of 3,921 citations were identified from the electronic database search. An additional 30 were added from a review of the grey literature. Figure 2 outlines the process used to determine which studies would be included in the review. A total of 110 articles were included.

Figure 2: Flow diagram of identification of studies

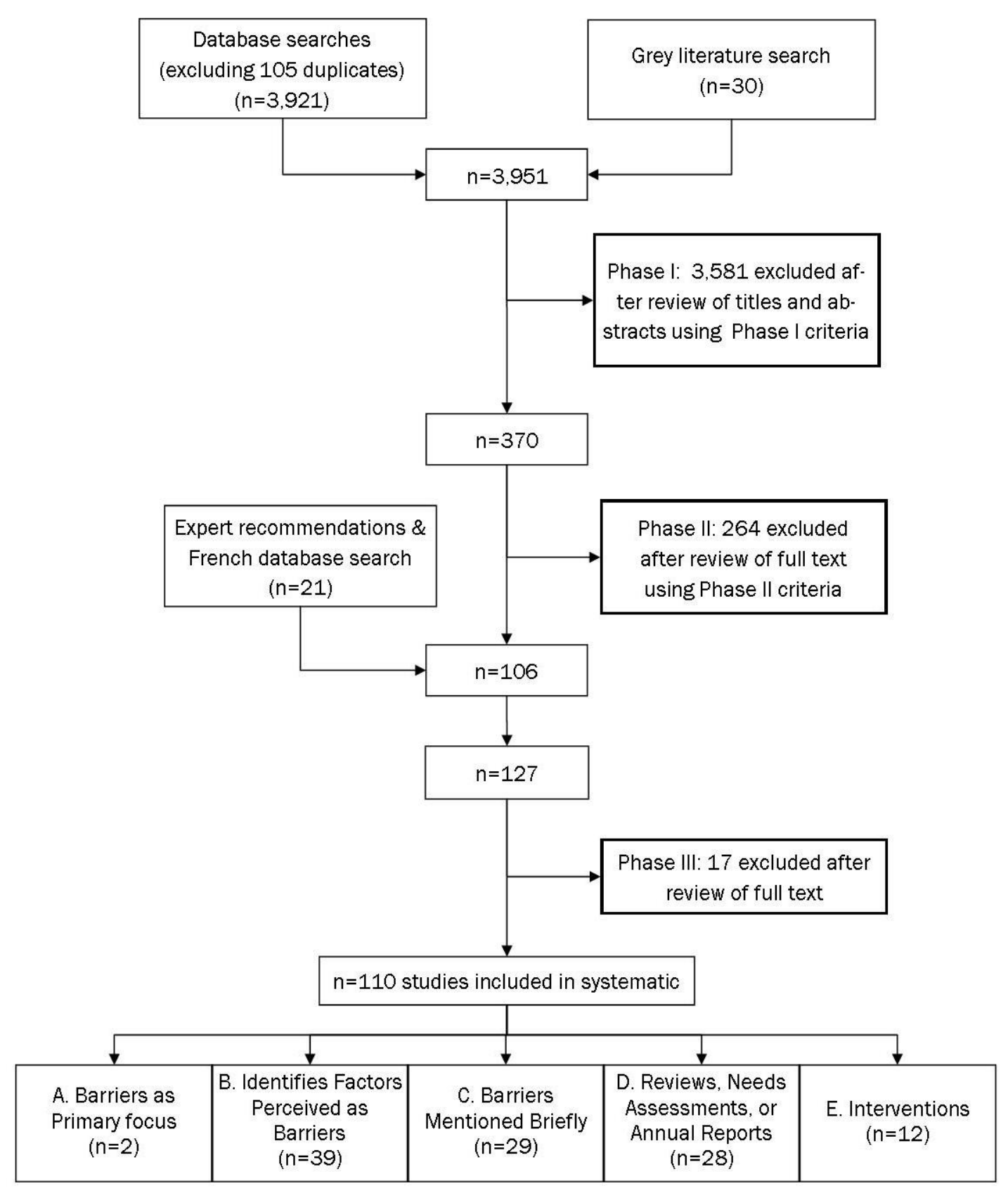




\section{METHODS FOR SYNTHESIS}

\section{Categorizing Studies}

Once articles included in the review were compiled in Excel, our researchers categorized them by the extent to which they discussed barriers to fistula treatment:

1. Barriers are a study's primary focus

2. Article identifies factors that reviewers perceived as barriers

3. Barriers are mentioned briefly in introduction or discussion but are not an article's primary focus

4. Reviews, needs assessments, or annual reports with some mention of barriers

5. Interventions aiming to remove barriers to fistula treatment

\section{Categorizing Barriers}

Based on the frequency of barrier themes identified in the articles included in this review, we categorized barriers into nine groups, and the studies mentioning each of these nine barriers were then tallied (and presented in Box 1 on the following page):
1. Psychosocial
6. Quality of Care
2. Transportation
7. Social
3. Cultural
8. Political
4. Facility shortages
9. Financial
5. Awareness

\section{Confidence in Findings Assessment (CFA) for Interventions}

The 12 studies of interventions removing barriers to treatment were analyzed to assess the extent to which barriers were reduced. Due to the range of different study outcomes and various study designs identified in this review, it was important to assess the quality of studies included and the confidence in the study findings for effective recommendations from the literature. In other systematic reviews, the purpose in assessing quality is to reduce the risk of bias in aggregating study results using the CONSORT checklist (Schulz et al. 2010) and the Newcastle-Ottawa Scale, although there are methodological concerns with NOS (Stang 2010). As in Meyer et al. (2011), our reviewers developed a "Confidence in Findings Assessment" (CFA) tool, although our version of the CFA did not draw from the NewcastleOttawa scale. In our qualitative assessment of study designs, participant selection, quality of comparison, and outcome measurement, each reviewer scored each study as high, medium, or low confidence overall. Studies with a reasonable counterfactual and strong description of the intervention were rated as high confidence. Articles describing study outcomes but without sufficient information on outcome attribution to the intervention were assigned medium confidence. Articles without a comparison group and a weak design were rated as low confidence (Table 6, Appendix D). 


\section{Results}

\section{TYPES OF BARRIERS AND CATEGORIZATION}

\section{Categorization and frequency of barriers}

The barriers identified in the 110 articles were grouped into nine categories (see Table 1 in Appendix B for an outline of the categories with bulleted descriptions from the articles). Box 1 outlines the frequency of articles that mentioned each barrier; articles often mentioned more than one barrier.

\section{Box 1: Studies mentioning barrier category}

\begin{tabular}{|lc|}
\hline Barrier Category & Frequency $^{2}$ \\
Financial & 71 \\
Facility Shortages & 65 \\
Social & 65 \\
Transportation & 62 \\
Quality of Care & 58 \\
Awareness & 57 \\
Cultural & 42 \\
Psychosocial & 30 \\
Political & 12 \\
\hline
\end{tabular}

In this section of the report, we describe the barriers mentioned in the surveyed articles in order of their frequency.

Financial

Financial barriers were the most frequently mentioned barriers in this review. Many articles reported that women experience barriers when attempting to access fistula treatment because the procedure is too costly. According to the Fistula Foundation (2014), the approximate average cost to treat obstetric fistula is US\$450-including surgery, postoperative care, and physical rehabilitation. This price estimate is based on average costs reported to the Fistula Foundation in 25 countries in sub-Saharan Africa and South Asia. Costs and length of hospitalization can vary by degree of fistula complexity. In response to unaffordable medical costs, some countries have introduced exemption policies to make certain health care services free. Ghana's Ministry of Health introduced an exemption policy that includes repair of vesico-vaginal and recto-vaginal fistulas. Significant problems with its implementation have been reported, however (Ofori-Adjei 2007).

\footnotetext{
2 Corresponds to the number of articles that mention each barrier; many articles mention more than one barrier to care.
} 


\section{Facility shortages}

Facility shortages are significant barriers and involve shortages of doctors, trained surgeons, and other personnel in addition to shortages of facilities themselves as well as equipment and supplies. These shortages contribute to the large numbers of women requiring repair, especially in rural areas.

\section{Social}

The high number of articles citing social barriers indicates that many women experience varying degrees of social stigma that can prevent them from seeking care. Women who experience fistula report feeling isolated or abandoned by their husbands, families, or communities, without anyone to accompany them to treatment facilities (Mselle et al. 2011, Aliyu and Esegbona 2011). Social barriers may also contribute to financial barriers; women who are abandoned by their husbands and families may find it more difficult to acquire funds for financing the procedure or transportation costs.

\section{Transportation}

Transportation and its costs were repeatedly cited as a barrier to care. A majority of women living with fistula are from remote, rural areas, and most fistula services are in urban centers. Women report that transportation is costly or sometimes non-existent. To overcome this challenge, in Kenya and Tanzania a mobile money service (MPESA) ${ }^{3}$ helped low-income women both save and prepay for fistula repair costs, and receive money for transportation (Bangser 2011, Finander 2012 and 2103). Even when transportation is available or affordable, women may experience too much pain or discomfort to travel, or may be turned away from public transportation due to their condition.

\section{Quality of care}

Perceived poor quality of care is a commonly cited barrier involving multiple facets of care. Although fistula is often surgically treatable, surgery is not always successful, especially when complex and involving both the vagina and rectum (recto-vaginal fistula), or when a woman has significant scar tissue. According to a retrospective review of fistula surgeries over 25 years in Nigeria, 82 percent were cured after one operation, with some women receiving two, three, four, or five surgeries total (Hilton and Ward 1998). Although the totally cured rate in this cohort was 98 percent, it is possible, in similar settings, that many women may be discouraged from multiple fistula surgeries after previous unsuccessful attempts. Even when a fistula is successfully closed, women may experience stress incontinence for several months or years after the surgery. The perception that women may continue to leak even after their "cure" may dissuade some women from choosing to seek care. Rural women who seek care for fistula may also face diagnosis or referral challenges, and long waiting times may delay their appropriate care because of the needs of acute conditions in other patients.

\footnotetext{
3 MPESA is a mobile money service whereby money can be sent, cashed, and saved via mobile telephone networks
} 


\section{Awareness}

Lack of awareness is a frequently mentioned barrier to seeking fistula treatment; many women who suffer from obstetric fistula do not know what fistula is, that their condition is treatable, or where to get treatment. Women with fistula and members of their community may also be misinformed about the causes of fistula. In some communities fistula is believed to be a curse or a punishment from God (Naidu and Donnay 2003, Muleta et al. 2008). Some women living with fistula, and some traditional birth attendants who assist women who develop fistula, believe that doctors caused fistulas during deliveries. When fistula is believed to be inflicted by God, or when fistula is believed to be caused by a doctor's actions, a woman living with fistula is unlikely to be interested in seeking treatment at a health facility.

\section{Cultural}

Cultural factors, which include male societal dominance, may act as barriers to care for some women. In some cultures (e.g. in Nigeria) “a perceived social need for women's reproductive capacities to be under strict male control" exists (Wall 1998). If women with fistula lack decision-making capabilities or control over household funds, whether facilities or transportation are readily available may not matter, as they may be unable to access treatment regardless. Male dominance influences women's reproductive and healthcare choices and may also contribute to women's development of fistula (Odhiambo 2010). Cultural barriers include negative attitudes toward medical clinics or doctors, and reliance upon traditional medicines or home remedies.

Psychosocial

Although psychosocial barriers were not cited as frequently as other barriers, they remain important factors that can influence a woman's care seeking decisions. Numerous studies reveal that women with obstetric fistula have a disproportionately high prevalence of depression (Goh et al. 2005, Alio et al. 2011, Mselle et al. 2011, Weston et al. 2011, Siddle et al. 2013). In addition to depression, studies report that women living with fistula experience anxiety, loss of dignity, and low self-worth (Wall 1998, Inbaraj 2004, Mselle et al. 2011, Narcisi et al. 2010). Researchers believe that such psychological symptoms can inhibit women's agency and motivation for seeking treatment.

\section{Political}

Political barriers were cited least frequently but are an important barrier to consider. Due to competing priorities, fistula repair (and maternal health in general) does not receive the attention and funding it requires. In low-income countries, governments may be overwhelmed with other medical problems (such as malaria or HIV) requiring a significant proportion of their attention and resources. Chronic conditions that do not directly result in death, such as obstetric fistula, are viewed as low priority. Additionally, civil war, political insecurity, and corruption are reported as barriers to seeking fistula repair services. 


\section{THE THREE DELAYS TO FISTULA TREATMENT}

Figure 1 (on page 5) is an adaptation of the Three Delays Model presented by Thaddeus and Maine (1994). The factors affecting utilization and outcome involve nine barriers to fistula treatment identified in the systematic review.

Psychosocial, cultural, awareness, and social barriers affect the Phase I decision of seeking care. Financial and transportation barriers affect both the decision to seek care and the ability to identify and reach a medical facility. If a woman living with fistula is aware that she is unable to access transportation to a repair center, she may decide not to seek care; if she initially decides to seek care, she may find herself unable to do so if transportation is unavailable or financially unfeasible. Facility shortages and quality of care affect both the decision to seek care, as well as receiving adequate and appropriate treatment. A woman with fistula may be dissuaded from deciding to seek care if she has heard about poor quality of care from other women in her community who have also experienced fistula; if she is able to seek care and reach a medical facility, poor quality of care may prevent her from receiving adequate and appropriate treatment. These eight barriers are affected by the broader political environment, which may itself be a barrier (or facilitator, where supportive policies exist) to treatment.

\section{TYPES OF ARTICLES AND CATEGORIZATION OF BARRIERS}

Tables 3 through 6 (Appendix $\mathrm{C}$ ) present all included articles in five categories based on the extent to which they address barriers to fistula treatment. The five categories include: articles with barriers to treatment as their primary focus; articles identifying factors that their researchers perceive as barriers; articles briefly mentioning barriers; reviews, needs assessments, or annual reports; and articles focusing on interventions that aim to reduce barriers to treatment. Each of the four tables presented in Appendix C include the treatment barriers addressed in each article.

\section{INTERVENTIONS TO ALLEVIATE BARRIERS TO FISTULA CARE}

The fifth category includes studies of interventions aiming to reduce barriers to treatment. Expanding on tables 2 through 5 in Appendix C, Appendix D's Table 6 presents detailed information that may help identify best practices and potential gaps or limitations. The table also assesses the quality of evidence on an intervention's effectiveness.

Eight studies were rated with high confidence, with their evidence presented clearly indicating that their interventions alleviated barriers identified during their study periods. Most of these studies targeted facility shortages, awareness, or transportation.

Three studies were rated with medium confidence, their evidence suggesting that they may have helped increase access to treatment, but unclear on whether the intervention itself resulted in the outcome, or whether the targeted population would have received treatment in the absence of the intervention. 
One study was rated with low confidence: an educational brochure aimed at increasing women's awareness. Its authors concluded it was an effective means, but it targeted only women already presenting for treatment, and the evidence did not measure its effectiveness in the wider population of all women suffering from fistula. Additionally, other studies report that the majority of women living with fistula are illiterate, and a brochure is likely to be unhelpful in increasing awareness.

\section{LIMITATIONS OF STUDIES OF INTERVENTIONS}

Several of the studies of interventions faced design limitations, raising questions of whether or not their observed outcomes were truly the result of their intervention or due to other factors. Many studies lacked comparison groups, limiting the ability to attribute any observed effect to their interventions. Only four of the 12 interventions had a comparison group. Three studies used before and after designs (Fiander et al. 2013, Bangser et al. 2011, USAID Aquire project 2007), in Kenya, Tanzania, and Ethiopia. One study in Nigeria tested information heard on the radio with non-listeners.

It was also difficult to ascertain, from the published descriptions of how interventions were implemented, whether their target populations were truly women unable to access treatment in the absence of those interventions. Additionally, despite the apparent success of intervention programs targeting facility shortages in the short term, such as the Fistula Fortnight concept in countries such as Nigeria (Ramsey 2007), it is unclear whether such interventions have lasting effects in removing barriers in the long term.

The literature search found few studies able to plausibly establish causality; many studies were unable to establish temporality between factors identified as barriers and the inability to access care, and between interventions and their reported outcomes. Due to the low number of studies with appropriate comparison groups, unbiased sampling methods, and effective controls for confounding variables, much analysis relied on information presented in interviews, observational studies, and country reports. The small number of scientific studies also prevents a meta-analysis, due to the lack of common outcome measures.

Additionally, many of the observational studies and interviews in this review were at health facilities. Although these studies present some valuable information, their populations of interest were women already presenting for, or receiving, fistula treatment. While it may be beneficial to determine which barriers made it difficult for those women to access care, they ultimately were able to access treatment. It would be better to focus research efforts on women with fistula who cannot access treatment. Identifying women with fistula who are unable to access care is difficult-most of these women are poor, illiterate, rural, lack awareness about their condition, and may be isolated from their communities-one factor why the literature is limited. Community-based studies are costly given the relatively low estimated fistula prevalence of approximately 1.57 obstetric fistula cases per 1,000 women in sub-Saharan Africa and South Asia (Adler et al. 2013)-even though this figure is likely an underestimate. 


\section{Discussion}

\section{IMPLICATION OF FINDINGS}

This review identifies several interventions with the aim of reducing barriers to fistula treatment. While this is encouraging, stronger monitoring and evaluation mechanisms are necessary for assessing the extent to which such interventions contribute to or accelerate access to fistula treatment. It is likely these interventions have played some part in treatment improvements, but without rigorous evaluations using experimental or quasiexperimental study designs, it is not possible to quantify their impact with validity. Generally, sampling was facility-based, with a lack of baseline data and plausible comparison groups.

Interventions targeting demand side barriers-psychosocial, awareness, social, and cultural-are also lacking. Interventions more frequently targeted financial barriers; this is understandable considering financial barriers were the most frequently reported barriers to care. To address financial barriers, many countries in Africa, and globally, are introducing user fee exemption policies to improve access to care and, consequently, improve maternal outcomes. Recent work from FEMHealth (2014), however, reports that the impacts of these policies are not well understood; they have found a range of both positive and negative outcomes in different contexts. This recent research highlights the importance of context, culture, and political frameworks in addition to the implementation of interventions and policies themselves.

This review identifies a shortage of studies focusing on identifying barriers to fistula treatment. Only two studies in this review had such an aim, but many studies identify factors that researchers perceived as treatment barriers. This review also reveals a lack of prevalence studies that could quantify the extent of the problem of untreated obstetric fistula. This gap in the literature could reflect both a logistical challenge in identifying relatively few cases, and an ethical challenge in justifying the cost of case identification, while offering practical solutions to women identified as a result of the research, especially in regions where there are few surgical options for repair.

Overall, more commitment is needed to address the barriers to care affecting women living with fistula. Solutions need a holistic approach and cannot focus on just one barrier-such as awareness or financial access-while neglecting psychosocial and cultural factors. Solutions must have a long term focus to ensure that initiatives contribute to an overall environmental shift, encouraging integration of fistula case identification and surgical care within comprehensive maternal health outreach and service delivery that will also contribute to obstetric fistula prevention, ultimately removing the need for fistula care services. 


\section{STRENGTHS AND LIMITATIONS OF THE RESEARCH APPROACH}

There are several strengths to using the approach and methods employed during this systematic review. The review was comprehensive: Almost 4,000 articles spanning more than 30 years were screened for inclusion. The articles reviewed include a broad range of different sources, including academic journals, case studies, country reports, needs assessments, and descriptions of campaign efforts. Articles addressing fistula in many lowincome countries were reviewed in both English and French. As a result of the wide range of countries included in this review, identified barriers can be considered applicable for potential studies and interventions in low-income regions where women remain at risk of fistula.

Additionally, the categorization of articles made it possible to demonstrate the degree to which articles addressed barriers to fistula treatment. Presenting review results in this way permits an exploration of the literature on fistula treatment barriers while also exploring the literature on related fistula topics, which helped contextualize the findings on barriers.

Despite its strengths, the systematic review of barriers to fistula treatment faces some limitations. Because fistula affects some of the most marginalized and powerless women in low-income countries, fistula is under researched, with few population-based studies, particularly studies of interventions to overcome delays in seeking fistula treatment. This review was limited to articles published either in English or French, and may have missed relevant articles in other languages

Certain factors identified as barriers in the review may be context specific and country dependent. For example, certain cultural barriers, including male control of household resources and wife seclusion, may only be applicable in certain regions. Similarly, the extent to which a factor identified as a barrier truly prevents a woman with fistula from seeking treatment is dependent on the woman's education, age, marital status, and community, and related factors. 


\section{Conclusions}

This review indicates, while barriers to fistula treatment may be easily identified, their alleviation is difficult and requires a sustainable and multi-faceted intervention targeting several barriers simultaneously. Rigorous studies of the determinants, prevalence, and distribution of fistula are lacking, in addition to studies documenting barriers to fistula treatment. The results presented in this review identify current evidence gaps that must be addressed by rigorous research so valid information can be generated to plan and implement future interventions for improving access to fistula treatment in low-income countries.

\section{RECOMMENDATIONS FOR FURTHER RESEARCH}

Based on this review, our recommendations for further research require studies systematically documenting implementation of interventions for removing supply and demand side barriers, and rigorously evaluating the effectiveness of their outcomes through quasi-experimental or experimental designs. Such studies may include the implementation of interventions that appeared effective in removing barriers to fistula treatment but which need evidence with greater validity, such as transportation schemes or radio messages. Future intervention studies must include plausible counterfactuals to better attribute their study outcomes to the interventions.

Additionally, population screening tools enabling health systems to systematically identify women with untreated fistula are needed to help inform women about their condition and treatment options. Such tools would also allow health systems to more precisely estimate their obstetric fistula burdens. Community-based research, instead of facility-based studies, is crucial for finding women with obstetric fistula who are unable to reach facilities, and thus are unable to access treatment. Combining fistula case identification, through community outreach, with rigorous surveillance methods for measuring prevalence would be a costefficient strategy for achieving two aims in one intervention.

Future interventions should test strategies for reducing stigma and improving community support to empower women living with fistula with the knowledge and means for seeking treatment. 


\section{References}

Adler, A.J., S. Fox, O.M.R. Campbell, H. Kuper. 2013. Obstetric fistula in Southern Sudan: situational analysis and Key Informant Method to estimate prevalence. BMC Pregnancy and Childbirth 13: 64. doi:10.1186/1471-2393-13-64

Ahmed, S. and S.A. Holtz. 2007. Social and economic consequences of obstetric fistula: life changed forever? International Journal of Gynaecology and Obstetrics: The Official Organ of the International Federation of Gynaecology and Obstetrics 99, Suppl 1: S10-5. doi:10.1016/j.ijgo.2007.06.011

Alio, A.P., L. Merrell, K. Roxburgh, H.B. Clayton, P.J. Marty, L. Bomboka, H.M. Salihu. 2011. The psychosocial impact of vesico-vaginal fistula in Niger. Archives of Gynecology and Obstetrics 284(2): 371-378. doi:10.1007/s00404-010-1652-5

Aliyu, F. and G. Esegbona. 2011. Living with obstetric fistula. BMJ (Clinical Research Ed.) 342: d2881. www.ncbi.nlm.nih.gov/pubmed/23245409

Amr, M.F. 1998. Vesico-vaginal fistula in Jordan. European Journal of Obstetrics, Gynecology, and Reproductive Biology 80(2): 201-203. www.sciencedirect.com/science/article/pii/S0301211598001031

Anoukoum, T., K.K. Attipou, L.K. Agoda-Koussema, K. Akpadza, E.A. Ayite. 2010. [Epidemiological, aetiological and treatment aspects of obstetrical fistula in Togo]. Progrès en Urologie: Journal de l'Association Française d'Urologie et de la Société Française d'Urologie 20(1): 71-76. doi:10.1016/j.purol.2009.08.038

Arrowsmith, S., E.C. Hamlin, L.L. Wall. 1996. Obstructed labor injury complex: obstetric fistula formation and the multifaceted morbidity of maternal birth trauma in the developing world. Obstetrical and Gynecological Survey 51(9): 568-574. www.ncbi.nlm.nih.gov/pubmed/8873157

Bacon, C. 2003. Obstetric Fistula Needs Assessment Report: Findings from Nine African Countries. [Rapport d'Evaluation sur les Besoins Inhérents à la Fistule Obstétrique: Résultats Issus de Neuf Pays Africains]. New York: United Nations Population Fund. www.unfpa.org/fistula/docs/fistula-needs-assessment.pdf

Bangser, M, B. Gumodoka, Z. Berege. 1999. A Comprehensive Approach to Vesico-vaginal Fistula: A Project in Mwanza, Tanzania. 157-165. Oxford: Blackwell Science.

Bangser, M. 2002. Tanzania Fistula Survey 2001. New York: United Nations Population Fund.

Bangser, M. 2007. Strengthening public health priority-setting through research on fistula, maternal health, and health inequities. International Journal of Gynaecology and Obstetrics: The Official Organ of the International Federation of Gynaecology and Obstetrics 99, Suppl 1: S16-20. doi:10.1016/j.ijgo.2007.06.016 
Bangser, M. 2011. Making Mobile Phones Work for Women with Fistula: The M-PESA

Experience in Kenya and Tanzania. New York: EngenderHealth, Fistula Care.

www.fistulacare.org/pages/pdf/technical-

briefs/mobile phone brief updated4.5.2011.pdf

Bangser, M. and A. Haile-Mariam. 2010. Assessment of USAID's Support for Fistula Activities in Ethiopia. [Unpublished]. http://pdf.usaid.gov/pdf_docs/PDACR602.pdf

Bangser, M., M. Mehta, C. Daly, C. Kamugumya, A. Mwangomale. 2011. Childbirth experiences of women with obstetric fistula in Tanzania and Uganda and their implications for fistula program development. International Urogynecology Journal 22(1): 91-98. doi: http://dx.doi.org/10.1007/s00192-010-1236-8

Baptiste, D., C. Kapungu, M.H. Khare, Y. Lewis, L. Barlow-Mosha. 2010. Integrating women's human rights into global health research: an action framework. Journal of Women's Health 19(11): 2091-2099. doi:10.1089/jwh.2010.2119

Barone, M.A., V. Frajzyngier, S. Arrowsmith, J. Ruminjo, A. Seuc, E. Landry, A.M. Gülmezoglu. 2012. Non-inferiority of short-term urethral catheterization following fistula repair surgery: study protocol for a randomized controlled trial. BMC Women's Health 12: 5. doi:10.1186/1472-6874-12-5

Bhutta, S. 1996. Vesicovaginal fistula-more than an obstetric problem. Journal of the Pakistan Medical Association 46(6): 135-136. www.thelancet.com/journals/lancet/article/PIIS0140-6736\%2806\%29694762/fulltext\#article_upsell

Blum, S. 2012. Living with obstetric fistula: qualitative research findings from Bangladesh and the Democratic Republic of Congo. New York: EngenderHealth, Fistula Care. www.fistulacare.org/pages/pdf/technicalbriefs/qualitative fistula brief final web8.13.2012.pdf

Browning, A. and T.L. Patel. 2004. FIGO initiative for the prevention and treatment of vaginal fistula. International Journal of Gynaecology and Obstetrics: The Official Organ of the International Federation of Gynaecology and Obstetrics 86(2): 317-22. doi:10.1016/j.ijgo.2004.05.003

Browning, A. 2007. Obstetric fistula: clinical considerations in the creation of a new urethra and the management of a subsequent pregnancy. International Journal of Gynaecology and Obstetrics: The Official Organ of the International Federation of Gynaecology and Obstetrics 99 Suppl 1: S94-97. doi:10.1016/j.ijgo.2007.06.023

Browning, A., W. Fentahun, J.T.W. Goh. 2007. The impact of surgical treatment on the mental health of women with obstetric fistula. BJOG : An International Journal of Obstetrics and Gynaecology 114(11): 1439-1441. doi:10.1111/j.1471-0528.2007.01419.x 
Browning, A. 2008. Obstetric fistula: current practicalities and future concerns. International Urogynecology Journal and Pelvic Floor Dysfunction 19(3): 333-334. doi:10.1007/s00192-007-0543-1

Cam, C., A. Karateke, A. Ozdemir, C. Gunes, C. Celik, B. Guney, D. Vatansever. 2010. Fistula campaigns--are they of any benefit? Taiwanese Journal of Obstetrics and Gynecology 49(3): 291-296. doi:10.1016/S1028-4559(10)60063-0

Capes, T., C. Ascher-Walsh et al. 2011. Obstetric fistula in low and middle income countries. The Mount Sinai Journal of Medicine, New York 78(3): 352-361. www.ncbi.nlm.nih.gov/pubmed/21598262

Cook, R.J., B.M. Dickens, S. Syed. 2004. Obstetric fistula: the challenge to human rights. International Journal of Gynaecology and Obstetrics: The Official Organ of the International Federation of Gynaecology and Obstetrics 87(1): 72-77. doi:10.1016/j.ijgo.2004.07.005

Creanga, A.A., S. Ahmed, R.R. Genadry, C. Stanton. 2007. Prevention and treatment of obstetric fistula: Identifying research needs and public health priorities. International Journal of Gynaecology and Obstetrics: The Official Organ of the International Federation of Gynaecology and Obstetrics 99, Suppl 1: S151-154. doi:10.1016/j.ijgo.2007.06.037

Devlyn, F.J. 2000. Rotary responds to women's health needs. International Journal of Gynaecology and Obstetrics: The Official Organ of the International Federation of Gynaecology and Obstetrics 70(1): 183-190. www.ncbi.nlm.nih.gov/pubmed/10884547

Donnay, F. and K. Ramsey. 2006. Eliminating obstetric fistula: progress in partnerships. International Journal of Gynaecology and Obstetrics: The Official Organ of the International Federation of Gynaecology and Obstetrics 94(3): 254-261. doi:10.1016/j.ijgo.2006.04.005

Donnay, F. and L. Weil. 2004. Obstetric fistula: the international response. Lancet 363(9402): 71-72. doi:10.1016/S0140-6736(03)15177-X

Donnelly, K, T. Yewondwossen, E. Oliveras, M. Belachew, M. Asnake. 2013. A Qualitative Analysis of the Experience of Women Supported by the Integrated Family Health Project to Reach Fistula Repair Services: Their Experience of Repair Services and Re-integration. Watertown, Ma.: Pathfinder International. www.pathfinder.org/publicationstools/pdfs/Fistula-FINAL-for-web.pdf? $x=112 \& y=17$

Ekanem, E.I., A.D. Ekanem, J.E. Ekabua, S.J. Etuk, A. Essiet. 2010. Review of obstetrics genitourinary fistulae in the University of Calabar Teaching Hospital Calabar, Nigeria. Nigerian Journal of Clinical Practice 13(3): 326-330. www.njcponline.com/temp/NigerJClinPract133326-1687411 044114.pdf

Elneil, S. and A. Browning. 2009. Obstetric fistula: a new way forward. BJOG : An International Journal of Obstetrics and Gynaecology 116, Suppl: 30-32. doi:10.1111/j.1471-

0528.2009.02309.x 
FEMHealth. 2014. Cost and Impact of Policies to Remove Fees for Obstetric Care in Benin, Burkina Faso, Mali and Morocco. www.abdn.ac.uk/femhealth/documents/Deliverables/Overall_cost_and_effects_report_fin al_14_04_14.pdf

Fiander, A. and T. Vanneste. 2012. transportMYpatient: an initiative to overcome the barrier of transport costs for patients accessing treatment for obstetric fistulae and cleft lip in Tanzania. Tropical Doctor 42(2): 77-79. doi:http://dx.doi.org/10.1258/td.2011.110423

Fiander, A., C. Ndahani, K. Mmuya, T. Vanneste. 2013. Results from 2011 for the transportMYpatient program for overcoming transport costs among women seeking treatment for obstetric fistula in Tanzania. International Journal of Gynaecology and Obstetrics: The Official Organ of the International Federation of Gynaecology and Obstetrics 120(3): 292-295. doi:10.1016/j.ijgo.2012.09.026

Fistula Foundation. 2014. Fast Facts and Frequently Asked Questions. www.fistulafoundation.org/what-is-fistula/fast-facts-faq

Gerten, K.A., S. Venkatesh, A.M. Norman, J. Shu'aibu, H.E. Richter. 2009. Pilot study utilizing a patient educational brochure at a vesicovaginal fistula hospital in Nigeria, Africa. International Urogynecology Journal and Pelvic Floor Dysfunction 20(1): 33-37. doi:10.1007/s00192-008-0720-x

Gharoro, E.P. and K.N. Agholor. 2009. Aspects of psychosocial problems of patients with vesico-vaginal fistula. Journal of Obstetrics and Gynaecology: The Journal of the Institute of Obstetrics and Gynaecology 29(7): 644-647. doi:10.1080/01443610903100609

Goh, J.T.W., H. Krause, A.B. Tessema, G. Abraha. 2013. Urinary symptoms and urodynamics following obstetric genitourinary fistula repair. International Urogynecology Journal 24(6): 947-51. doi:10.1007/s00192-012-1948-z

Goh, J.T.W., K.M. Sloane, H.G. Krause, A. Browning, S. Akhter. 2005. Mental health screening in women with genital tract fistulae. BJOG : An International Journal of Obstetrics and Gynaecology 112(9): 1328-1330. doi:10.1111/j.1471-0528.2005.00712.x

Hamlin, E.C., M. Muleta, R.C. Kennedy. 2002. Providing an obstetric fistula service. BJU International 89, Suppl 1: 50-53. http://onlinelibrary.wiley.com/doi/10.1046/j.14655101.2001.129.x/pdf

Hardee, K., J. Gay, A.K. Blanc. 2012. Maternal morbidity: neglected dimension of safe motherhood in the developing world. Global Public Health 7(6): 603-617. doi:10.1080/17441692.2012.668919

Hassan, M.A. and B.A. Ekele. 2009. Vesicovaginal fistula: do the patients know the cause? Annals of African Medicine 8(2): 122-126. doi:10.4103/1596-3519.56241 
Heller, A. 2014. Bedside manner and the invisible patient: The silence surrounding women's gynaecological health in Niger. Anthropology Today 30(1): 20-23. doi:10.1111/14678322.12086

Henry, J.A., O. Windapo, A.L. Kushner, R.S. Groen, B.C. Nwomeh. 2012. A survey of surgical capacity in rural southern Nigeria: opportunities for change. World Journal of Surgery 36(12): 2811-2818. doi:10.1007/s00268-012-1764-0

Hilton, P. and A. Ward. 1998. Epidemiological and surgical aspects of urogenital fistulae: a review of 25 years' experience in southeast Nigeria. International Urogynecology Journal and Pelvic Floor Dysfunction 9(4): 189-94. http://download.springer.com/static/pdf/119/art\%253A10.1007\%252FBF01901602.pd f?auth66=1404549090_27301ed418c55956b1400a061dd6ecc4\&ext $=. p d f$

Hinrichsen, D., C. Richey, B. Robey, F. Muller. 2004. Obstetric Fistula: Ending the Silence, Easing the Suffering. Baltimore, Md.: Johns Hopkins Bloomberg School of Public Health INFO project. www.k4health.org/sites/default/files/ObstetricFistula.pdf

Iliyasu, Z., L. Idoko, K. Ramsey. 2007. The Fistula Fortnight: Healing Wounds, Renewing Hope, 21 February-6 March 2005, Kano, Katsina, Kebbi and Sokoto States, Nigeria. New York: United Nations Population Fund.

Inbaraj, S. 2004. Married as Children, Women with Obstetric Fistulas Have No Future. Washington, D.C.: Population Reference Bureau. www.prb.org/Publications/Articles/2004/MarriedasChildrenWomenWithObstetricFistulasH aveNoFuture.aspx

Ismail, S.I.M.F. 2008. Obstetric fistula; guiding principles for clinical management and programme development. (Eds. G. Lewis and L.de Bernis). International Urogynecology Journal 20(2): 271-271. doi:10.1007/s00192-008-0739-z

Jones, D. 2007. Living testimony: Obstetric fistula and inequities in maternal health. New York: Family Care International. www.unfpa.org/webdav/site/global/shared/documents/publications/2007/living fistula eng.pdf

Kane, Y. and K. Ramsey. 2004. Report of the Africa Regional Fistula Meeting, Campaign to End Fistula, Accra, Ghana, 29 June-1 July 2004. New York: United Nations Population Fund. www.unfpa.org/webdav/site/global/shared/documents/publications/2004/fistula_accrar eport.pdf

Kalilani-Phiri, L.V, E. Umar, D. Lazaro, J. Lunguzi, A. Chilungo. 2010. Prevalence of obstetric fistula in Malawi. International Journal of Gynaecology and Obstetrics: The Official Organ of the International Federation of Gynaecology and Obstetrics 109(3): 204-208. doi:10.1016/j.ijgo.2009.12.019 
Keri, L., D. Kaye, K. Sibylle. 2010. Referral practices and perceived barriers to timely obstetric care among Ugandan traditional birth attendants (TBA). African Health Sciences 10(1): 75-81.

www.pubmedcentral.nih.gov/articlerender.fcgi?artid=2895798\&tool=pmcentrez\&renderty pe=abstract

Khisa, A.M. and I.K. Nyamongo. 2012. Still living with fistula: an exploratory study of the experience of women with obstetric fistula following corrective surgery in West Pokot, Kenya. Reproductive Health Matters 20(40): 59-66. doi:10.1016/S09688080(12)40661-9

Krijgh, E., B. Campbell, T. Abraha. 2003. Mending Torn Lives: A Series of Open Conversations with Women Suffering from Obstetric Fistula in Eritrea. United Nations Population Fund in collaboration with the Ministry of Health. www.endfistula.org/sites/endfistula.org/files/pub-pdf/mendingtornlives.pdf

Lassey, A.T. 2007. Simple fistulas: diagnosis and management in low-resource settings: a descriptive report. International Journal of Gynaecology and Obstetrics: The Official Organ of the International Federation of Gynaecology and Obstetrics 99, Suppl 1: S47-50. doi:10.1016/j.ijgo.2007.06.025

Lewis, G. and L. de Bernis. 2006. Obstetric fistula: guiding principles for clinical management and programme development. Nursing Times 102(29): 27. www.ncbi.nlm.nih.gov/pubmed/16895244

Marcus, C., L. Gibney, E. Landry. 2009. Fistula Pre-repair Center Model in the Amhara Region of Ethiopia. New York: EngenderHealth, Fistula Care. www.engenderhealth.org/files/pubs/fistula-care-digitalarchive/1/1.1/ethiopia_brief_fistula_pre_repair.pdf

Matsamura, E. 2004. Uganda's Fistula Patients Lack Knowledge of Prevention and Treatment. Washington, D.C.: Population Reference Bureau. www.prb.org/Publications/Articles/2004/UgandasFistulaPatientsLackKnowledgeofPreven tionandTreatment.aspx

Maulet, N., M. Keita, J. Macq. 2013. Medico-social pathways of obstetric fistula patients in Mali and Niger: an 18-month cohort follow-up. Tropical Medicine and International Health 18(5): 524-533. doi:10.1111/tmi.12086

McFadden, E., S.J. Taleski, A. Bocking, R.F. Spitzer, H. Mabeya. 2011. Retrospective review of predisposing factors and surgical outcomes in obstetric fistula patients at a single teaching hospital in Western Kenya. Journal of Obstetrics and Gynaecology Canada: JOGC=Journal D'obstétrique et Gynécologie Du Canada: JOGC 33(1): 30-35.

Mehta, M. and M. Bangser. 2006. Risk and resilience: Obstetric fistula in Tanzania. Dar es Salaam: Women's Dignity Project. www.engenderhealth.org/files/pubs/maternalhealth/Risk-and-Resilience-Obstetric-Fistula-in-Tanzania.pdf 
Mehta, M., M. Bangser, N. Barber, J. Lindsay, M. Gujrati. 2007. Sharing the Burden: Ugandan Women Speak About Obstetric Fistula. Dar es Salaam: Women's Dignity Project. www.fistulacare.org/pages/pdf/SharingtheBurden UgandanWomenSpeakAboutObstetricF istula.pdf

Melah, G.S., A.A. Massa, U.R. Yahaya, M. Bukar, D.D. Kizaya, A.U. El-Nafaty. 2007. Risk factors for obstetric fistulae in north-eastern Nigeria. Journal of Obstetrics and Gynaecology: The Journal of the Institute of Obstetrics and Gynaecology 27(8): 819-823. doi:10.1080/01443610701709825

Meyer, C., N. Bellows, M. Campbell, M. Potts. 2011. The Impact of Vouchers on the Use and Quality of Health Goods and Services in Developing Countries: A Systematic Review. London: EPPI-Centre, Social Science Research Unit, Institute of Education, University of London. http://eppi.ioe.ac.uk

Miller, S., F. Lester, M. Webster, B. Cowan. (n.d.). Obstetric fistula: a preventable tragedy. Journal of Midwifery and Women's Health 50(4): 286-294. doi:10.1016/j.jmwh.2005.03.009

Mselle, L.T., K.M. Moland, B. Evjen-Olsen, A. Mvungi, T.W. Kohi. 2011. "I am nothing”: experiences of loss among women suffering from severe birth injuries in Tanzania. BMC Women's Health 11: 49. doi:10.1186/1472-6874-11-49

Mukisa, B. and E. Cole. 2013. Creating an enabling environment for fistula prevention and treatment in Uganda. New York: EngenderHealth, Fistula Care www.fistulacare.org/pages/pdf/technical-briefs/Uganda_TWG_TB_FINAL_3_28_13.pdf

Muleta, M., M. Fantahun, B. Tafesse, E.C. Hamlin, R.C. Kennedy. 2007. Obstetric fistula in rural Ethiopia. East African Medical Journal 84(11): 525-533. www.ncbi.nlm.nih.gov/pubmed/18303745

Muleta, M., E.C. Hamlin, M. Fantahun, R.C. Kennedy, B. Tafesse. 2008. Health and social problems encountered by treated and untreated obstetric fistula patients in rural Ethiopia. Journal of Obstetrics and Gynaecology Canada: JOGC=Journal D'obstétrique et Gynécologie Du Canada: JOGC 30(1): 44-50.

Nafiou, I., A. Idrissa, A.K. Ghaïchatou, M.L. Roenneburg, C.R. Wheeless, R.R. Genadry. 2007. Obstetric vesico-vaginal fistulas at the National Hospital of Niamey, Niger. International Journal of Gynaecology and Obstetrics: The Official Organ of the International Federation of Gynaecology and Obstetrics 99, Suppl 1: S71-74. doi:10.1016/j.ijgo.2007.06.012

Naidu, A. and F. Donnay. 2003. Untreated fistula: a condition of shame and shunning. Global HealthLink 123: 3.

Narcisi, L., A. Tieniber, L. Andriani, T. McKinney. 2010. The fistula crisis in sub-Saharan Africa: an ongoing struggle in education and awareness. Urologic Nursing 30(6): 341-346. www.ncbi.nlm.nih.gov/pubmed/21261194 
Nathan, L.M., C.H. Rochat, B. Grigorescu, E. Banks. 2009. Obstetric fistulae in West Africa: patient perspectives. American Journal of Obstetrics and Gynecology 200(5): e40-42. doi:10.1016/j.ajog.2008.10.014.

Ndiaye, P., G. Amoul Kini, I. Abdoulaye, M. Diagne Camara, A. Tal-Día. 2009. [Epidemiology of Women Suffering from Obstetric Fistula in Niger]. Médecine Tropicale : Revue du Corps de Santé Colonial 69(1): 61-65. www.ncbi.nlm.nih.gov/pubmed/19499737

Nielsen, H.S., L. Lindberg, U. Nygaard, H. Aytenfisu, O.L. Johnston, B. Sørensen, S. Duffy. 2009. A community-based long-term follow up of women undergoing obstetric fistula repair in rural Ethiopia. BJOG: An International Journal of Obstetrics and Gynaecology 116(9): 1258-1264. doi:10.1111/j.1471-0528.2009.02200.x

Obaid, E. and T. Chong. 2004. Healing wounds, instilling hope: The Tanzanian Partnership against Obstetric Fistula. New York: Population Council.

Odhiambo, A. 2010. "I am not dead, but I am not living:" barriers to fistula prevention and treatment in Kenya. Human Rights Watch. www.hrw.org/sites/default/files/reports/kenya0710webwcover.pdf

Ofori-Adjei, D. 2007. Ghana's free delivery care policy. [editorial]. Ghana Medical Journal 41(3): 94-96. www.ncbi.nIm.nih.gov/pmc/articles/PMC2279087

Ojanuga, D. 1994. Social work practice with childbirth-injured women in Nigeria. Health \& Social Work 19(2): 120-124. www.ncbi.nIm.nih.gov/pubmed/8045445

Ojengbede, O.A., I.O. Morhason-Bello, O. Shittu. 2007. One-stage repair for combined fistulas: myth or reality? International Journal of Gynaecology and Obstetrics: The Official Organ of the International Federation of Gynaecology and Obstetrics 99, Suppl 1: S90-93. doi:10.1016/j.ijgo.2007.06.022

Raassen, T. 2006. VVF Treatment and Training through Outreach Services: AMREF Experience. East and Central African Journal of Surgery 11(1): 25-27. www.bioline.org.br/request?js06006

Ramsey, K., Z. Iliyasu, L. Idoko. 2007. Fistula Fortnight: innovative partnership brings mass treatment and public awareness towards ending obstetric fistula. International Journal of Gynaecology and Obstetrics: The Official Organ of the International Federation of Gynaecology and Obstetrics 99, Suppl 1: S130-136. doi:10.1016/j.ijgo.2007.06.034

Ramsey, K. and A. Pinel. 2007. Where Urology and Obstetrics Meet: The Campaign to End Fistula. International Journal of Urological Nursing 1(1): 48-52. doi:10.1111/j.1749771X.2007.00009.x

Rijken, Y. and G.C. Chilopora. 2007. Urogenital and recto-vaginal fistulas in southern Malawi: a report on 407 patients. International Journal of Gynaecology and Obstetrics: The Official Organ of the International Federation of Gynaecology and Obstetrics 99, Suppl 1: S85-89. doi:10.1016/j.ijgo.2007.06.015 
Roush, K., A. Kurth, M.K. Hutchinson, N. Van Devanter. 2012. Obstetric fistula: what about gender power? Health Care for Women International 33(9): 787-798.

doi:10.1080/07399332.2011.645964

Ruminjo, J. 2007. Obstetric Fistula and the Challenge to Maternal Health Care Systems. Medical Bulletin 41(4). http://issuu.com/ippfresources/docs/medical_bulletin_december07

Rushwan, H., S. Khaddaj, L. Knight, R. Scott. 2012. Need for a global obstetric fistula training strategy. International Journal of Gynaecology and Obstetrics: The Official Organ of the International Federation of Gynaecology and Obstetrics 119, Suppl: S76-79. doi:10.1016/j.ijgo.2012.03.022

Samba, A. and E. Sinclair. 2004. Obstetric Fistula: A Needs Assessment in Ghana and Rwanda: Expanding Our Knowledge. New York: EngenderHealth.

Schulz, K.F., D.G. Altman, D. Moher. 2010. CONSORT 2010 statement: Updated guidelines for reporting parallel group randomised trials. BMC Medicine $8(18)$.

doi:10.1016/j.ijsu.2010.09.006

Shittu, O.S., O.A. Ojengbede, L.H.I. Wara. 2007. A review of postoperative care for obstetric fistulas in Nigeria. International Journal of Gynaecology and Obstetrics 99: S79-S84. doi:10.1016/j.ijgo.2007.06.014

Siddle, K., S. Mwambingu, T. Malinga, A. Fiander. 2013. Psychosocial impact of obstetric fistula in women presenting for surgical care in Tanzania. International Urogynecology Journal 24(7): 1215-1220. doi:10.1007/s00192-012-1994-6

Slinger, G., L. Laski, R. Ndlovu, E. Anastasi, J. Kabba-Kebbay, E. Franca, R. Desiderio. 2013. Practices on Ending the Health and Human Rights Tragedy of Obstetric Fistula. United Nations Population Fund.

Sombie, I., T. Kambou, S.G. Conombo, O. Sankara, L. Ouedraogo, T. Zoungrana, N. Meda. 2007. [Retrospective Study of Urogenital Fistula in Burkina Faso from 2001 to 2003]. Médecine Tropicale: Revue du Corps de Santé Colonial 67(1): 48-52. www.ncbi.nlm.nih.gov/pubmed/17506273

Stang, A. 2010. Critical evaluation of the Newcastle-Ottawa scale for the assessment of the quality of nonrandomized studies in meta-analyses. European Journal of Epidemiology 25(9): 603-605.

Sunday-Adeoye, E. and E. Landry. 2012. Community-based Screening for Obstetric Fistula in Ebonyi State, Nigeria. New York: EngenderHealth, Fistula Care. www.fistulacare.org/pages/pdf/technical-briefs/ebonyi_community screening4.5.2012.pdf

Tebeu, P.M., L. de Bernis, L. Boisrond, A. Le Duc, A.A. Mbassi, C.H. Rochat. 2008. [Knowledge, Attitude and Perception of Obstetric Fistula by Cameroonian Women]. Progrès en Urologie: 
Journal de l'Association Française d'Urologie et de la Société Française d'Urologie 18(6): 379-389. doi:10.1016/j.purol.2008.03.020

Teghrarian, S. and K. Ramsey. 2003. South Asia Conference for the Prevention and Treatment of Obstetric Fistula, 9-11 December 2003, Dhaka, Bangladesh. Report. Dhaka: United Nations Population Fund. www.unfpa.org/webdav/site/global/shared/documents/publications/2004/fistula_asiare port.pdf

Thaddeus, S. and D. Maine. 1994. Too far to walk: Maternal mortality in context. Social Science and Medicine 38(8): 1091-1110. doi:10.1016/0277-9536(94)90226-7

Turan, J.M., K. Johnson, M.L. Polan. 2007. Experiences of women seeking medical care for obstetric fistula in Eritrea: implications for prevention, treatment, and social reintegration. Global Public Health 2(1): 64-77. doi:10.1080/17441690600648728

United Nations. 2012. Supporting efforts to end fistula: Report of the secretary general.

United Nations Population Fund. 2003. The Second meeting of the Working Group for the Prevention and Treatment of Obstetric Fistula, Addis Ababa, 30 October -1 November, 2002. New York: UNFPA.

United Nations Population Fund. 2012. Maternal health thematic fund: Annual Report 2012. UNFPA.

United Nations Population Fund South Sudan. 2012. Obstetric fistula campaign in South Sudan. UNFPA.

Umoiyoho, A.J., E.C. Inyang-Etoh, E.A. Etukumana. 2012. Obstetric fistula repair: experience with hospital-based outreach approach in Nigeria. Global Journal of Health Science 4(5): 40-45. www.ccsenet.org/journal/index.php/gjhs/article/viewFile/17225/12377

United States Agency for International Development. 2010. A collaborative network to improve access to fistula treatment in Nigeria. New York: EngenderHealth, Fistula Care. www.fistulacare.org/pages/pdf/technical-briefs/Nigeria_pooled effort_brief_.pdf

United States Agency for International Development ACQUIRE. 2007. The ACQUIRE Project Final Report: Obstetric Fistula in Amhara Regional State, Ethiopia, January 2006-March 2007. Cooperative Agreement GPO-A-00-03600006-00. New York: EngenderHealth, ACQUIRE Project. www.acquireproject.org/fileadmin/user upload/ACQUIRE/ACQUIREFistula Final Report with appendices - 070531.pdf

Velez, A., K. Ramsey, K. Tell. 2007. The Campaign to End Fistula: what have we learned? Findings of facility and community needs assessments. International Journal of Gynaecology and Obstetrics: The Official Organ of the International Federation of Gynaecology and Obstetrics 99, Suppl 1: S143-150. doi:10.1016/j.ijgo.2007.06.036 
Waiz, N., M. Farugul, A. Begum, N. Sultana, S. Sarker, J. Falsel. 2003. Situation analysis of obstetric fistula in Bangladesh: Report. Dhaka: EngenderHealth. www.engenderhealth.org/files/pubs/maternal-health/bangladesh-fistula-report.pdf

Wall, L.L. 1998. Dead mothers and injured wives: the social context of maternal morbidity and mortality among the Hausa of northern Nigeria. Studies in Family Planning 29(4): 341359. www.ncbi.nlm.nih.gov/pubmed/9919629

Wall, L.L. 2005. Hard questions concerning fistula surgery in Third World countries. [editorial]. Journal of Women's Health 14(9): 863-866. www.ncbi.nlm.nih.gov/pubmed/16313216

Wall, L.L., S.D. Arrowsmith, N.D. Briggs, A. Browning, A. Lassey. 2005. The obstetric vesicovaginal fistula in the developing world. Obstetrical \& Gynecological Survey 60(7, Suppl 1): S3-S51. www.ics.org/Publications/ICl_3/v2.pdf/chap22.pdf

Wall, L.L., S.D. Arrowsmith, A.T. Lassey, K. Danso. 2006. Humanitarian ventures or "fistula tourism?": the ethical perils of pelvic surgery in the developing world. International Urogynecology Journal and Pelvic Floor Dysfunction 17(6): 559-562. doi:10.1007/s00192-005-0056-8

Wall, L.L. 2007. Where should obstetric vesico-vaginal fistulas be repaired: at the district general hospital or a specialized fistula center? International Journal of Gynaecology and Obstetrics: The Official Organ of the International Federation of Gynaecology and Obstetrics 99, Suppl 1: S28-31. doi:10.1016/j.ijgo.2007.06.019

Wegner, M.N., J. Ruminjo, E. Sinclair, L. Pesso, M. Mehta. 2007. Improving community knowledge of obstetric fistula prevention and treatment. International Journal of Gynaecology and Obstetrics: The Official Organ of the International Federation of Gynaecology and Obstetrics 99, Suppl 1: S108-111. doi:10.1016/j.ijgo.2007.06.030

Weston, K., S. Mutiso, J.W. Mwangi, Z. Qureshi, J. Beard, P. Venkat. 2011. Depression among women with obstetric fistula in Kenya. International Journal of Gynaecology and Obstetrics: The Official Organ of the International Federation of Gynaecology and Obstetrics 115(1): 31-33. doi:10.1016/j.ijgo.2011.04.015

Williams, G. 2007. The Addis Ababa Fistula Hospital: An holistic approach to the management of patients with vesicovaginal fistulae. Surgeon-Journal of The Royal Colleges of Surgeons of Edinburgh and Ireland 5(1): 54-57.

World Health Organization. 2009. Fistule obstetricale: Principes directeurs pour la prise en charge clinique et le developpement de programmes.

World Health Organization. 2006. Obstetric fistula: guiding principles for clinical management and program development. http://whqlibdoc.who.int/publications/2006/9241593679 eng.pdf 
Yeakey, M.P., E. Chipeta, F. Taulo, A.O. Tsui. 2009. The lived experience of Malawian women with obstetric fistula. Culture, Health and Sexuality 11(5): 1. doi:http://dx.doi.org/10.1080/13691050902874777

Yeakey, M.P., E. Chipeta, Y. Rijken, F. Taulo, A.O. Tsui. 2011. Experiences with fistula repair surgery among women and families in Malawi. Global Public Health 6(2): 153-67. doi:10.1080/17441692.2010.491833

Zheng, A.X. and F.W.J. Anderson. 2009. Obstetric fistula in low-income countries. International Journal of Gynaecology and Obstetrics: The Official Organ of the International Federation of Gynaecology and Obstetrics 104(2): 85-89. doi:10.1016/j.ijgo.2008.09.011 


\title{
Appendix A
}

\author{
Data Extraction Form \\ Fistula Project 2014 \\ * Required \\ Title * \\ Authors * \\ Publication Date * \\ Journal/Source * \\ O AJOG \\ BJOB \\ BMCPC \\ EAMJ \\ IJGO \\ OIUJPFD \\ JOG \\ JWH \\ The Lancet \\ OG \\ SM \\ SS\&M \\ Health Policy and Planning \\ Other: \\ Study Design * \\ Cohort \\ Case Control \\ Cross Sectional \\ Ecological
}


Clinical Trial

Case Study

Interview

Report

Other:

Country *

Length of Study

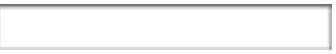

Population of interest

Age, location sampled from, socioeconomic status, have fistula or not, treated or untreated

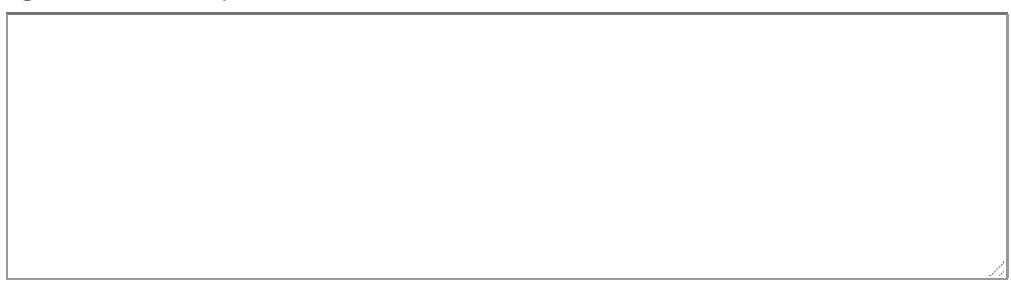

Setting/sampling frame

sampled from a heatlh facility or household (general population)?

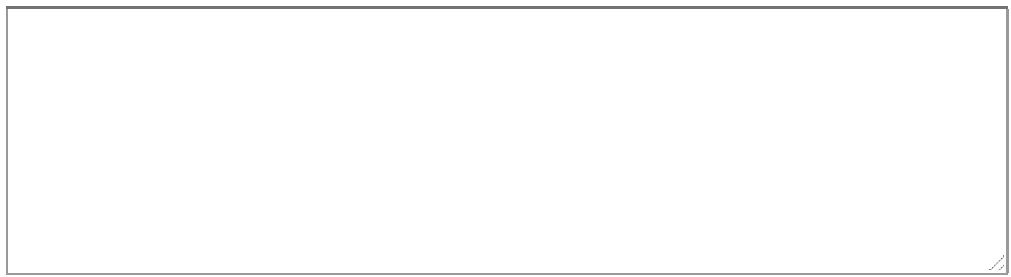

Control/comparison group

Yes or no? Who? E.g. comparing treated women to untreated women 


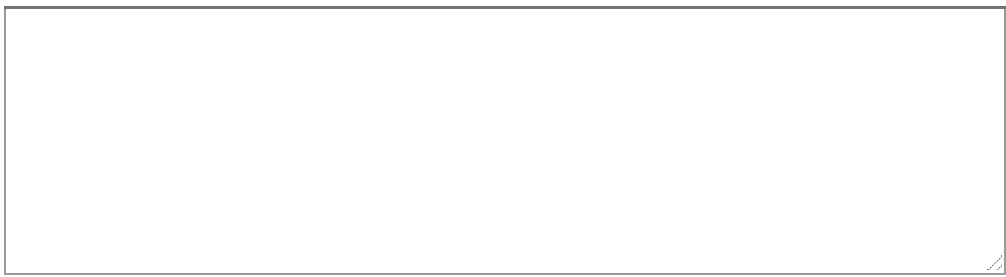

Intervention

Yes or no? Describe.

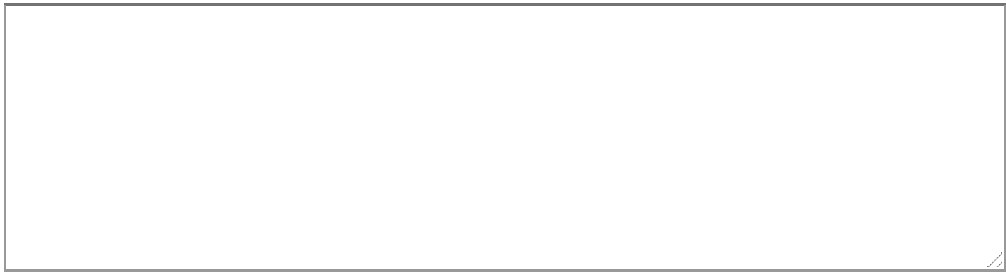

\section{Outcomes *}

Barriers identified, outcome of intervention (improve service utilization, improve quality of fistula repair, improve community-based detection and referral of fistula)

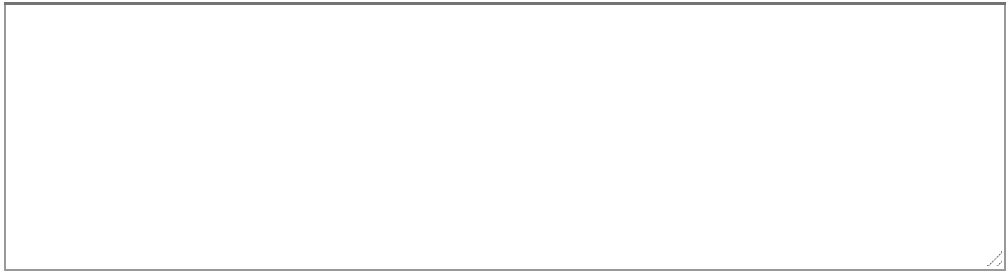

Other details or Notes *

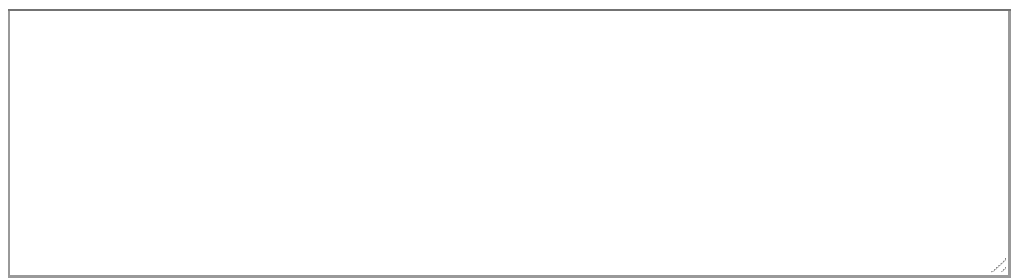

Submit

Never submit passwords through Google Forms.

Powered by Google Docs 


\section{Appendix B}

Table 1: Categorization of barriers to treatment of fistula

\begin{tabular}{|c|c|}
\hline Psychosocial & $\begin{array}{ll}- & \text { depression } \\
- & \text { loss of dignity and self-worth } \\
- & \text { anxiety }\end{array}$ \\
\hline \begin{tabular}{|l} 
Cultural \\
\end{tabular} & $\begin{array}{ll}- & \text { societal male dominance } \\
- & \text { domestic responsibility } \\
\text { - } & \text { practice of wife seclusion } \\
\text { - } & \text { male control of money } \\
\text { - } & \text { requiring permission from husbands to seek care } \\
\text { - } & \text { other forms of gender power imbalance } \\
- & \text { negative attitudes about medical clinics or doctors } \\
- & \text { restrictions on female mobility } \\
- & \text { reliance on traditional medicine and home remedies } \\
- & \text { belief that hospitals are places where people go to die } \\
- & \text { unwilling to be referred to clinics or hospitals because they } \\
& \text { were nervous about learning their HIV status }\end{array}$ \\
\hline Awareness & $\begin{array}{ll} & \text { unaware that fistula is treatable } \\
\text { - } & \text { lack of information about fistula } \\
\text { - } & \text { perception that fistula was caused by a doctor } \\
\text { - } & \text { lack of community awareness on ability to treat fistula } \\
\text { - } & \text { fear of surgery } \\
\text { - } & \text { not knowing where to go for treatment } \\
\text { - } & \text { belief that fistula is a punishment from god }\end{array}$ \\
\hline Social & $\begin{array}{ll}- & \text { isolation } \\
- & \text { abandonment or divorce from husband } \\
- & \text { women are unable to find someone who would accompany } \\
& \text { them } \\
\text { - } & \text { loss of, or lack of, social support } \\
-\quad & \text { too embarrassed to go to a hospital because of own smell } \\
- & \text { relatives hide the presence of a family member with fistula }\end{array}$ \\
\hline \begin{tabular}{|l|} 
Financial \\
\end{tabular} & $\begin{array}{ll}- & \text { cost of procedure is unaffordable } \\
\text { - } & \text { poverty and cannot afford care } \\
\text { - } & \text { lost job and cannot afford care }\end{array}$ \\
\hline Transportation & $\begin{array}{ll}\text { - } & \text { cost of travel and accommodation is high } \\
\text { - } & \text { lack of transportation } \\
\text { - } & \text { pain and discomfort } \\
\text { - } & \text { perineal nerve damage affecting the ability to walk, or foot- } \\
\text { - } & \text { drop, and other physical mobility issues } \\
\text { - } & \text { surgeons are far away and repairs are rarely at local hospitals } \\
\text { - } & \text { most hospitals capable of performing repairs are in urban } \\
\text { areas }\end{array}$ \\
\hline
\end{tabular}




\begin{tabular}{|c|c|}
\hline & $\begin{array}{ll}- & \text { long distance to health facility } \\
\text { - } & \text { unable to take public transit (smell, leaking) } \\
\text { - } & \text { rugged physical landscape } \\
\text { - } & \text { poor condition of roads }\end{array}$ \\
\hline $\begin{array}{l}\text { Facility } \\
\text { shortages } \\
\text { (trained } \\
\text { personnel and } \\
\text { equipment) }\end{array}$ & $\begin{array}{ll}\text { - } & \text { shortage of health workers } \\
\text { - } & \text { insufficient repair resources } \\
\text { - } & \text { lack of specialized surgeons } \\
\text { - } & \text { no electricity at hospital } \\
\text { - } & \text { lack of doctors } \\
\text { - } & \text { lack of doctors and nurses } \\
\text { - } & \text { limited availability of operating rooms and equipment } \\
\text { - } & \text { administrative delays and clinical mismanagement } \\
\text { - } & \text { few facilities providing repairs } \\
\text { - } & \text { shortage of female health providers }\end{array}$ \\
\hline Quality of Care & $\begin{array}{ll}\text { - } & \text { told by health workers that it would repair itself } \\
\text { - } & \text { past unsuccessful repairs } \\
\text { - } & \text { incontinence even after successful repair } \\
\text { - } & \text { fistula patients require longer hospitalization than general } \\
& \text { surgery patients } \\
\text { - } & \text { multiple referrals } \\
\text { - } & \text { diagnosis challenges } \\
\text { - } & \text { inadequate training for fistula repair } \\
\text { - } & \text { verbal and physical abuse from doctors and nurses } \\
\text { - } & \text { poor quality of care } \\
\text { - } & \text { fistula patients seen as a low priority } \\
\text { - } & \text { limited knowledge of fistula among health workers } \\
\text { - } & \text { poor communication, or miscommunication, from health } \\
\text { - } & \text { long workers }\end{array}$ \\
\hline Political & $\begin{array}{ll}\text { - } & \text { fistula not recognized as a public health problem } \\
\text { - } & \text { underfunding of fistula programs } \\
\text { - } & \text { corruption } \\
\text { - } & \text { civil war and/or political insecurity } \\
\text { - } & \text { governments are overwhelmed by other priorities } \\
\text { - } & \text { limited political commitment to maternal health }\end{array}$ \\
\hline
\end{tabular}




\section{Appendix C}

\section{Table 2: Barriers as Primary Focus}

\begin{tabular}{|l|l|l|}
\hline $\begin{array}{l}\text { Location and Time } \\
\text { Frame }\end{array}$ & Barriers Identified & References \\
\hline $\begin{array}{l}\text { Eritrea } \\
\text { (Nov - Dec 2004) }\end{array}$ & $\begin{array}{l}\text { Awareness, Transportation, Quality } \\
\text { of Care, Social, Financial }\end{array}$ & Turan et al. 2007 \\
\hline $\begin{array}{l}\text { Ethiopia } \\
\text { (Jun 2011) }\end{array}$ & $\begin{array}{l}\text { Awareness, Facility Shortages, } \\
\text { Financial, Transportation, } \\
\text { Psychosocial }\end{array}$ & Donnelly et al. 2013 \\
\hline
\end{tabular}

\section{Table 3: Identified Factors Perceived as Barriers}

\begin{tabular}{|l|l|l|}
\hline $\begin{array}{l}\text { Location and Time } \\
\text { Frame }\end{array}$ & Barriers Identified & References \\
\hline $\begin{array}{l}\text { Africa \& Asia (25 } \\
\text { Countries) } \\
\text { (2003 - 2005) }\end{array}$ & $\begin{array}{l}\text { Political, Awareness, Cultural, } \\
\text { Transportation, Facility Shortages, } \\
\text { Financial }\end{array}$ & Velez et al. 2007 \\
\hline $\begin{array}{l}\text { African \& Asian } \\
\text { Countries }\end{array}$ & Transportation & Adler et al. 2013 \\
\hline $\begin{array}{l}\text { Bangladesh \& DRC } \\
\text { (2006- 2010) }\end{array}$ & $\begin{array}{l}\text { Cultural, Transportation, } \\
\text { Awareness, Psychosocial, Social, } \\
\text { Quality of Care }\end{array}$ & Blum 2012 \\
\hline $\begin{array}{l}\text { Bangladesh \& Ethiopia } \\
\text { (2003 - 2004) }\end{array}$ & Psychosocial, Social & Goh et al. 2005 \\
\hline Benin & Awareness, Financial, Cultural & Nathan et al. 2009 \\
\hline $\begin{array}{l}\text { Cameroon } \\
\text { (May - Jul 2005) }\end{array}$ & Awareness & Tebeu et al. 2008 \\
\hline $\begin{array}{l}\text { Countries not } \\
\text { specified }\end{array}$ & $\begin{array}{l}\text { Facility Shortages, Quality of Care, } \\
\text { Social, Financial, Transportation }\end{array}$ & Wall 2007 \\
\hline Low-income countries & Social, Cultural & Roush et al. 2012 \\
\hline $\begin{array}{l}\text { Low-income countries } \\
\text { Transportation, Financial, Quality } \\
\text { of Care, Facility Shortages, Social, } \\
\text { Cultural }\end{array}$ & $\begin{array}{l}\text { Thaddeus \& Maine, } \\
1994\end{array}$ \\
\hline $\begin{array}{l}\text { DRC, Ethiopia, Guinea, } \\
\text { Kenya, Niger, Nigeria, } \\
\text { Sierra Leone, Uganda } \\
\text { (2 years) }\end{array}$ & $\begin{array}{l}\text { Facility Shortages, Transportation, } \\
\text { Financial }\end{array}$ & Barone et al. 2012 \\
\hline $\begin{array}{l}\text { Ethiopia } \\
\text { (Dec 2004 - Jul 2006) }\end{array}$ & $\begin{array}{l}\text { Financial, Psychosocial, Quality of } \\
\text { Care }\end{array}$ & Nielsen et al. 2009 \\
\hline
\end{tabular}




\begin{tabular}{|c|c|c|}
\hline $\begin{array}{l}\text { Location and Time } \\
\text { Frame }\end{array}$ & Barriers Identified & References \\
\hline $\begin{array}{l}\text { Ethiopia } \\
\text { (Jan - Jun 2005) }\end{array}$ & $\begin{array}{l}\text { Social, Psychosocial, Awareness, } \\
\text { Transportation }\end{array}$ & Muleta et al. 2008 \\
\hline Ethiopia & $\begin{array}{l}\text { Transportation, Financial, Cultural, } \\
\text { Social }\end{array}$ & Muleta et al. 2007 \\
\hline $\begin{array}{l}\text { Ethiopia } \\
\text { (Feb - Apr 2005) }\end{array}$ & Psychosocial & Browning et al. 2007 \\
\hline $\begin{array}{l}\text { Ethiopia } \\
\text { (Dec 2008 - Sep } \\
\text { 2009) }\end{array}$ & Quality of Care & Goh et al. 2013 \\
\hline Ghana \& Rwanda & Quality of Care, Financial & Lassey 2007 \\
\hline $\begin{array}{l}\text { Jordan } \\
(1972-1996)\end{array}$ & Quality of Care & Amr 1998 \\
\hline $\begin{array}{l}\text { Kenya } \\
\text { (Aug 2008) }\end{array}$ & $\begin{array}{l}\text { Psychosocial, Social, Financial, } \\
\text { Awareness, Transportation, Quality } \\
\text { of Care, Cultural }\end{array}$ & Weston et al. 2011 \\
\hline $\begin{array}{l}\text { Kenya } \\
\text { (2 months) }\end{array}$ & $\begin{array}{l}\text { Social, Quality of Care, } \\
\text { Psychosocial, Financial }\end{array}$ & $\begin{array}{l}\text { Khisa \& Nyamongo } \\
2012\end{array}$ \\
\hline $\begin{array}{l}\text { Malawi } \\
\text { (Jun - Oct 2007) }\end{array}$ & $\begin{array}{l}\text { Transportation, Social, Facility } \\
\text { Shortages, Quality of Care } \\
\text { Awareness, Cultural }\end{array}$ & Yeakey et al. 2011 \\
\hline Malawi & $\begin{array}{l}\text { Awareness, Financial, } \\
\text { Transpiration, Cultural, Quality of } \\
\text { Care, Facility Shortages }\end{array}$ & $\begin{array}{l}\text { Kalilani-Phiri et al. } \\
2010\end{array}$ \\
\hline $\begin{array}{l}\text { Malawi } \\
\text { (Jun 2007) }\end{array}$ & $\begin{array}{l}\text { Social, Psychosocial, Facility } \\
\text { Shortages, Cultural, Quality of } \\
\text { Care, Awareness }\end{array}$ & Yeakey et al. 2009 \\
\hline $\begin{array}{l}\text { Malawi } \\
\text { (Jan } 1997 \text { - Oct } \\
\text { 2005) }\end{array}$ & Facility Shortages, Quality of Care & $\begin{array}{l}\text { Rijken \& Chilopora } \\
2007\end{array}$ \\
\hline Niger & $\begin{array}{l}\text { Cultural, Awareness, Financial, } \\
\text { Transportation, Facility Shortages, } \\
\text { Quality of Care }\end{array}$ & Heller 2014 \\
\hline Niger & $\begin{array}{l}\text { Quality of Care, Facility Shortages, } \\
\text { Awareness }\end{array}$ & Cam et al. 2010 \\
\hline $\begin{array}{l}\text { Niger } \\
(2008-2009)\end{array}$ & $\begin{array}{l}\text { Social, Psychosocial, Financial, } \\
\text { Transportation, Cultural, Quality of } \\
\text { Care }\end{array}$ & Alio et al. 2011 \\
\hline Niger (2006) & Financial & Ndiaye et al. 2009 \\
\hline
\end{tabular}




\begin{tabular}{|c|c|c|}
\hline $\begin{array}{l}\text { Location and Time } \\
\text { Frame }\end{array}$ & Barriers Identified & References \\
\hline Nigeria & Quality of Care & Ojengbede et al. 2007 \\
\hline $\begin{array}{l}\text { Nigeria } \\
\text { (Nov 2011) }\end{array}$ & Facility Shortages & Henry et al. 2012 \\
\hline $\begin{array}{l}\text { Nigeria } \\
\text { (Mar - Sep 2007) }\end{array}$ & $\begin{array}{l}\text { Social, Cultural, Financial, } \\
\text { Psychosocial }\end{array}$ & Gharoro et al. 2009 \\
\hline Nigeria & $\begin{array}{l}\text { Awareness, Facility Shortages, } \\
\text { Transportation, Financial, Cultural }\end{array}$ & Wall 1998 \\
\hline $\begin{array}{l}\text { Nigeria } \\
\text { (3 years) }\end{array}$ & Quality of Care & Umoiyoho et al. 2012 \\
\hline $\begin{array}{l}\text { Nigeria } \\
\text { (Jun - Aug 2003) }\end{array}$ & $\begin{array}{l}\text { Awareness, Transportation, } \\
\text { Cultural }\end{array}$ & Hassan \& Ekele 2009 \\
\hline $\begin{array}{l}\text { Nigeria \& Sudan } \\
\text { (Mar 2005 - Aug } \\
\text { 2006) }\end{array}$ & Financial & Ojengbede et al. 2007 \\
\hline $\begin{array}{l}\text { South Sudan } \\
\text { (Jan - Feb 2012) }\end{array}$ & $\begin{array}{l}\text { Facility Shortages, Social, } \\
\text { Financial, Awareness, Quality of } \\
\text { Care }\end{array}$ & Adler et al. 2013 \\
\hline $\begin{array}{l}\text { Tanzania } \\
\text { (Oct 2008- Feb } \\
\text { 2010) }\end{array}$ & $\begin{array}{l}\text { Social, Psychosocial, Facility } \\
\text { Shortages, Quality of Care, Cultural }\end{array}$ & Mselle et al. 2011 \\
\hline $\begin{array}{l}\text { Tanzania } \\
\text { (Mar - May 2012) }\end{array}$ & $\begin{array}{l}\text { Transportation, Social, } \\
\text { Psychosocial }\end{array}$ & Siddle et al. 2013 \\
\hline Tanzania \& Uganda & $\begin{array}{l}\text { Transportation, Financial, Facility } \\
\text { Shortages }\end{array}$ & Bangser 2007 \\
\hline $\begin{array}{l}\text { Tanzania and Uganda } \\
(2003-2005)\end{array}$ & $\begin{array}{l}\text { Facility Shortages, Social, } \\
\text { Financial, Psychosocial, Quality of } \\
\text { Care, Awareness, Transportation, } \\
\text { Cultural }\end{array}$ & Bangser et al. 2011 \\
\hline Uganda & $\begin{array}{l}\text { Financial, Facility Shortages, } \\
\text { Awareness, Social }\end{array}$ & Mukisa \& Cole 2013 \\
\hline Uganda & $\begin{array}{l}\text { Quality of Care, Cultural, Financial, } \\
\text { Social, Transportation, Awareness }\end{array}$ & Keri et al. 2010 \\
\hline
\end{tabular}




\section{Table 4: Barriers Briefly Mentioned}

\begin{tabular}{|c|c|c|}
\hline Location and Time Frame & Barriers Identified & References \\
\hline Country not specified & Quality of Care & Wall et al. 2006 \\
\hline Country not specified & $\begin{array}{l}\text { Transportation, Financial, } \\
\text { Facility Shortages, Quality } \\
\text { of Care }\end{array}$ & Elneil \& Browning 2009 \\
\hline Country not specified & $\begin{array}{l}\text { Transportation, Social, } \\
\text { Cultural, Awareness, } \\
\text { Financial, Facility } \\
\text { Shortages }\end{array}$ & Miller et al. 2005 \\
\hline Country not specified & $\begin{array}{l}\text { Social, Financial, } \\
\text { Psychosocial }\end{array}$ & Ahmed \& Holtz 2007 \\
\hline Country not specified & $\begin{array}{l}\text { Cultural, Social, } \\
\text { Transportation, Financial, } \\
\text { Facility Shortages }\end{array}$ & Naidu \& Donnay 2003 \\
\hline Low-income countries & Social, Financial & Wall et al. 2005 \\
\hline Low-income countries & $\begin{array}{l}\text { Financial, Awareness, } \\
\text { Facility Shortages, Social, } \\
\text { Psychosocial }\end{array}$ & Hardee et al. 2012 \\
\hline Low-income countries & $\begin{array}{l}\text { Facility Shortages, } \\
\text { Political, Social, Financial, } \\
\text { Transportation, } \\
\text { Awareness, Cultural, } \\
\text { Quality of Care }\end{array}$ & Capes et al. 2011 \\
\hline Low-income countries & $\begin{array}{l}\text { Social, Financial, } \\
\text { Transportation, Facility } \\
\text { Shortages, Quality of Care }\end{array}$ & Cook et al. 2004 \\
\hline Low-income countries & $\begin{array}{l}\text { Social, Transportation, } \\
\text { Financial, Awareness, } \\
\text { Facility Shortages, Quality } \\
\text { of Care }\end{array}$ & Donnay \& Weil 2004 \\
\hline Low-income countries & $\begin{array}{l}\text { Awareness, Financial, } \\
\text { Quality of Care, Facility } \\
\text { Shortages }\end{array}$ & Creanga et al. 2007 \\
\hline Low-income countries & $\begin{array}{l}\text { Social, Awareness, } \\
\text { Financial, Psychosocial, } \\
\text { Facility Shortages }\end{array}$ & Ramsey \& Pinel 2007 \\
\hline Burkina Faso (2001-2003) & Cultural & Sombie 2007 \\
\hline Ethiopia & $\begin{array}{l}\text { Social, Financial, } \\
\text { Transportation, Quality of }\end{array}$ & Inbaraj 2004 \\
\hline
\end{tabular}




\begin{tabular}{|c|c|c|}
\hline Location and Time Frame & Barriers Identified & References \\
\hline & Care, Cultural & \\
\hline Ethiopia & $\begin{array}{l}\text { Social, Psychosocial, } \\
\text { Financial, Quality of Care, } \\
\text { Transportation, Facility } \\
\text { Shortages }\end{array}$ & Browning 2007 \\
\hline Ethiopia & $\begin{array}{l}\text { Transportation, Financial, } \\
\text { Facility Shortages, Social, } \\
\text { Quality of Care }\end{array}$ & Hamlin, et al. 2002 \\
\hline Ethiopia & $\begin{array}{l}\text { Transportation, Social, } \\
\text { Financial, Quality of Care, } \\
\text { Awareness, Facility } \\
\text { Shortages }\end{array}$ & Devlyn 2000 \\
\hline Ethiopia & $\begin{array}{l}\text { Financial, Facility } \\
\text { Shortages, Transportation, } \\
\text { Social, Quality of Care, } \\
\text { Psychosocial, Awareness }\end{array}$ & Williams 2007 \\
\hline Kenya & $\begin{array}{l}\text { Quality of Care, } \\
\text { Transportation, Financial }\end{array}$ & McFadden, et al. 2011 \\
\hline $\begin{array}{l}\text { Mali \& Niger } \\
(2008-2009)\end{array}$ & Quality of Care, Social & Maulet et al. 2013 \\
\hline $\begin{array}{l}\text { Niger } \\
\text { (Dec } 2003 \text { - Feb 2005) }\end{array}$ & $\begin{array}{l}\text { Social, Quality of Care, } \\
\text { Awareness, Cultural } \\
\text { Facility Shortages }\end{array}$ & Nafiou et al. 2007 \\
\hline Niger & $\begin{array}{l}\text { Social, Psychosocial, } \\
\text { Transportation, Financial, } \\
\text { Facility Shortages, Cultural }\end{array}$ & Narcisi et al. 2010 \\
\hline $\begin{array}{l}\text { Nigeria } \\
\text { (5 years) }\end{array}$ & $\begin{array}{l}\text { Social, Psychosocial, } \\
\text { Facility Shortages, } \\
\text { Financial }\end{array}$ & Ekanem et al. 2010 \\
\hline Nigeria & $\begin{array}{l}\text { Financial, Social, } \\
\text { Transportation, Facility } \\
\text { Shortages }\end{array}$ & Melah et al. 2007 \\
\hline Nigeria & $\begin{array}{l}\text { Cultural, Transportation, } \\
\text { Financial, Awareness, } \\
\text { Psychosocial, Social }\end{array}$ & Ojanuga 1994 \\
\hline Pakistan & $\begin{array}{l}\text { Transportation, Facility } \\
\text { Shortages, Cultural, } \\
\text { Quality of Care }\end{array}$ & Bhutta 1996 \\
\hline
\end{tabular}




\begin{tabular}{|l|l|l|}
\hline Location and Time Frame & Barriers Identified & References \\
\hline Tanzania & $\begin{array}{l}\text { Facility Shortages, } \\
\text { Transportation, } \\
\text { Awareness, Financial, } \\
\text { Quality of Care }\end{array}$ & Obaid \& Chong 2004 \\
\hline $\begin{array}{l}\text { Tanzania } \\
\text { (Mar 1997- Nov 1998) }\end{array}$ & $\begin{array}{l}\text { Facility shortages, } \\
\text { Awareness }\end{array}$ & Bangser et al. 1999 \\
\hline $\begin{array}{l}\text { Togo } \\
\text { (Jan 2001 - Dec 2005) }\end{array}$ & $\begin{array}{l}\text { Financial, Transportation, } \\
\text { Quality of Care }\end{array}$ & Anoukoum et al. 2010 \\
\hline Uganda & $\begin{array}{l}\text { Awareness, Social, } \\
\text { Transportation, Financial, } \\
\text { Facility Shortages }\end{array}$ & Matsamura 2004 \\
\hline
\end{tabular}

Table 5: Reviews, Needs Assessments, or Annual Reports

\begin{tabular}{|l|l|l|}
\hline Location and Time Frame & Barriers Identified & References \\
\hline $\begin{array}{l}30 \text { countries in Africa, } \\
\text { South Asia, and the Arab } \\
\text { World } \\
\text { (2003-2006) }\end{array}$ & $\begin{array}{l}\text { Facility shortages, } \\
\text { Financial }\end{array}$ & Donnay \& Ramsey 2006 \\
\hline 31 Low-income countries & $\begin{array}{l}\text { Financial, Transportation, } \\
\text { Awareness, Cultural, } \\
\text { Social, Psychosocial, } \\
\text { Quality of Care, Political, } \\
\text { Facility Shortages }\end{array}$ & Jones 2007 \\
\hline African countries & $\begin{array}{l}\text { Transportation, Political, } \\
\text { Financial, Social, } \\
\text { Awareness }\end{array}$ & Kane \& Ramsey 2004 \\
\hline Bangladesh & $\begin{array}{l}\text { Facility Shortages, } \\
\text { Awareness, Financial, } \\
\text { Social, Quality of Care, } \\
\text { Transportation, } \\
\text { Psychosocial, Cultural }\end{array}$ & Waiz et al. 2003 \\
\hline $\begin{array}{l}\text { Bangladesh, India, Nepal, } \\
\text { Pakistan }\end{array}$ & $\begin{array}{l}\text { Social, Financial, } \\
\text { Psychosocial, Awareness, } \\
\text { Political, Cultural, } \\
\text { Transportation, Facility } \\
\text { Shortages }\end{array}$ & 2003 \\
\hline Benin, Chad, Kenya, & $\begin{array}{l}\text { Transportation, Political, } \\
\text { Facility Shortages, }\end{array}$ & UNFPA 2003 \\
Malawi, Mali, & \multicolumn{2}{|c|}{ Teghrarian \&ey } \\
\hline
\end{tabular}




\begin{tabular}{|c|c|c|}
\hline Location and Time Frame & Barriers Identified & References \\
\hline $\begin{array}{l}\text { Mozambique, Niger, } \\
\text { Nigeria, Tanzania, Uganda, } \\
\text { Zambia } \\
\text { (2 years) }\end{array}$ & Awareness, Financial & \\
\hline $\begin{array}{l}\text { Benin, Chad, Malawi, Mali, } \\
\text { Mozambique, Niger, } \\
\text { Nigeria, Uganda, } \\
\text { Zimbabwe } \\
\text { (6 months) }\end{array}$ & $\begin{array}{l}\text { Social, Quality of Care, } \\
\text { Financial, Facility } \\
\text { Shortages, Political, } \\
\text { Cultural, Transportation, } \\
\text { Financial }\end{array}$ & Bacon 2003 \\
\hline Countries not specified & Social & Zheng \& Anderson 2009 \\
\hline Countries not specified & $\begin{array}{l}\text { Social, Facility Shortages, } \\
\text { Quality of Care, Cultural, } \\
\text { Psychosocial, Financial }\end{array}$ & Hinrichsen et al. 2004 \\
\hline Countries not specified & $\begin{array}{l}\text { Awareness, } \\
\text { Transportation, Financial, } \\
\text { Facility Shortages, Social }\end{array}$ & Lewis \& de Bernis 2006 \\
\hline Countries not specified & $\begin{array}{l}\text { Awareness, Facility } \\
\text { Shortages }\end{array}$ & $\begin{array}{l}\text { Organisation mondiale de } \\
\text { la Sante } 2009\end{array}$ \\
\hline Country not specified & $\begin{array}{l}\text { Transportation, } \\
\text { Awareness, Social, Quality } \\
\text { of Care, Cultural }\end{array}$ & Wegner et al. 2007 \\
\hline Country not specified & $\begin{array}{l}\text { Quality of Care, Facility } \\
\text { Shortages, Political, } \\
\text { Transportation, Cultural, } \\
\text { Social, Financial }\end{array}$ & Ruminjo 2007 \\
\hline Low-income countries & Social, Financial & UNFPA 2012 \\
\hline Low-income countries & Social, Facility Shortages & Rushwan et al. 2012 \\
\hline Low-income countries & $\begin{array}{l}\text { Financial, Awareness, } \\
\text { Quality of Care, Social, } \\
\text { Psychosocial, Facility } \\
\text { Shortages, Transportation }\end{array}$ & UN 2012 \\
\hline Low-income countries & $\begin{array}{l}\text { Cultural, Transportation, } \\
\text { Financial, Social }\end{array}$ & Wall 2005 \\
\hline $\begin{array}{l}\text { Eritrea } \\
\text { (Sept - Oct 2002) }\end{array}$ & $\begin{array}{l}\text { Transportation, Cultural, } \\
\text { Financial, Facility } \\
\text { Shortages, Quality of Care, }\end{array}$ & Krijgh et al. 2003 \\
\hline
\end{tabular}




\begin{tabular}{|l|l|l|}
\hline Location and Time Frame & Barriers Identified & References \\
\hline & Social & \\
\hline $\begin{array}{l}\text { Ethiopia } \\
\text { (12 days) }\end{array}$ & $\begin{array}{l}\text { Transportation, Facility } \\
\text { Shortages }\end{array}$ & $\begin{array}{l}\text { Bangser \& Haile-Mariam } \\
2010\end{array}$ \\
\hline Ethiopia & $\begin{array}{l}\text { Cultural, Social, Financial, } \\
\text { Facility Shortages, } \\
\text { Awareness }\end{array}$ & Browning \& Patel 2004 \\
\hline $\begin{array}{l}\text { Ghana \& Rwanda } \\
\text { (May - Oct 2002) }\end{array}$ & $\begin{array}{l}\text { Facility Shortages, } \\
\text { Awareness, } \\
\text { Transportation, Political, } \\
\text { Cultural, Financial }\end{array}$ & Samba \& Sinclair 2004 \\
\hline $\begin{array}{l}\text { Kenya } \\
\text { (Nov - Dec 2009) }\end{array}$ & $\begin{array}{l}\text { Social, Psychosocial, } \\
\text { Cultural, Awareness, } \\
\text { Financial, Facility } \\
\text { Shortages, Quality of Care, } \\
\text { Political }\end{array}$ & Odhiambo 2010 \\
\hline Niger (2009) & $\begin{array}{l}\text { Awareness, Facility } \\
\text { shortage, Transportation }\end{array}$ & Ndiaye et al. 2009 \\
\hline Sierra Leone \& Tanzania & $\begin{array}{l}\text { Political, Awareness, } \\
\text { Transportation, Social, } \\
\text { Facility Shortages }\end{array}$ & Slinger et al. 2013 \\
\hline $\begin{array}{l}\text { Uganda } \\
\text { (Apr - Jul 2005) }\end{array}$ & $\begin{array}{l}\text { Facility Shortages, Social, } \\
\text { Psychosocial, Awareness }\end{array}$ & UNFPA South Sudan 2012 \\
\hline Tanzania \\
(Jul 2003- Sep 2005) & $\begin{array}{l}\text { Financial, Quality of Care, } \\
\text { Social, Transportation, } \\
\text { Awareness }\end{array}$ & Mehta \& Bangser 2006 \\
\hline Tanzania & $\begin{array}{l}\text { Transportation, Facility } \\
\text { Shortages, Financial, } \\
\text { Quality of Care, Social } \\
\text { Social, Financial, Quality of } \\
\text { Psychosocial }\end{array}$ & Bangser 2002 \\
\hline
\end{tabular}




\section{Appendix D}

Table 6: Interventions to alleviate barriers to fistula care

\begin{tabular}{|c|c|c|c|c|c|c|c|c|c|}
\hline & Reference & $\begin{array}{l}\text { Location / } \\
\text { Time } \\
\text { Frame }\end{array}$ & $\begin{array}{l}\text { Study } \\
\text { Population }\end{array}$ & $\begin{array}{l}\text { Compari } \\
\text { son } \\
\text { Group }\end{array}$ & $\begin{array}{l}\text { Demand-side } \\
\text { Interventions }\end{array}$ & $\begin{array}{l}\text { Supply-side } \\
\text { Interventions }\end{array}$ & $\begin{array}{l}\text { Barrier } \\
\text { Targeted }\end{array}$ & Outcomes & $\begin{array}{l}\text { CFA } \\
\text { Grade }\end{array}$ \\
\hline 1. & Bangser 2011 & $\begin{array}{l}\text { Kenya \& } \\
\text { Tanzania } \\
\text { (Jul } 2009 \\
\text { - Nov } \\
2010 \text { ) }\end{array}$ & $\begin{array}{l}\text { Women in } \\
\text { Tanzania } \\
\text { and Kenya }\end{array}$ & $\begin{array}{l}\text { Pre- } \\
\text { interven } \\
\text { tion } \\
\text { fistula } \\
\text { repairs }\end{array}$ & $\begin{array}{l}\text { Kenya: M-PESA is a } \\
\text { mobile application } \\
\text { that helps low- } \\
\text { income women } \\
\text { save and prepay } \\
\text { for fistula repair } \\
\text { costs. } \\
\text { Public education } \\
\text { campaigns on } \\
\text { radio station } \\
\text { regarding fistula, } \\
\text { and a hotline. } \\
\text { Tanzania: hotline } \\
\text { established for } \\
\text { patients to get } \\
\text { information about } \\
\text { treatment }\end{array}$ & $\begin{array}{l}\text { Tanzania: Fistula } \\
\text { repair surgery } \\
\text { provider CCBRT } \\
\text { and UNFPA added } \\
20 \text { beds to existing } \\
\text { building for women } \\
\text { awaiting fistula } \\
\text { repair; CCBRT paid } \\
\text { for transport costs } \\
\text { for patients via M- } \\
\text { PESA }\end{array}$ & $\begin{array}{l}\text { Financial; } \\
\text { Transportation } \\
\text {; Awareness; } \\
\text { Facility } \\
\text { Shortages }\end{array}$ & $\begin{array}{l}\text { Kenya: Increase in } \\
\text { fistula patients from } \\
15 \text { to } 40 \text { per month. } \\
\text { Hotline received } \\
\text { nearly } 600 \text { calls from } \\
\text { Jan - Oct } 2010 . \\
230 \text { women funded } \\
\text { for fistula repair } \\
\text { (including transport } \\
\text { and follow-up). } \\
\text { Tanzania: CCBRT } \\
\text { hotline received } \\
\text { more than } 20 \text { calls } \\
\text { per day. } \\
54 \text { ambassadors } \\
\text { referred } 120 \text { women } \\
\text { for fistula repair from } \\
\text { Jan - Nov } 2010 . \\
60 \% \text { increase in } \\
\text { patients after M- } \\
\text { PESA }\end{array}$ & High \\
\hline 2. & $\begin{array}{l}\text { Bangser et al. } \\
1999\end{array}$ & $\begin{array}{l}\text { Tanzania } \\
\text { (Mar } \\
1997- \\
\text { Nov } \\
1998)\end{array}$ & $\begin{array}{l}\text { Women } \\
\text { with } \\
\text { untreated } \\
\text { fistula in } \\
\text { Mwanza } \\
\text { Tanzania }\end{array}$ & None & $\begin{array}{l}\text { Radio messages } \\
\text { about fistula } \\
\text { treatment at BMC }\end{array}$ & $\begin{array}{l}\text { Training } 1 \text { doctor } \\
\text { and } 2 \text { nurses from } \\
\text { BMC at Addis } \\
\text { Ababa Fistula } \\
\text { Hospital; on-site } \\
\text { workshops for } 70 \\
\text { health workers in } \\
\text { Mwanza }\end{array}$ & $\begin{array}{l}\text { Facility } \\
\text { shortages; } \\
\text { Awareness }\end{array}$ & None mentioned & Low \\
\hline
\end{tabular}




\begin{tabular}{|c|c|c|c|c|c|c|c|c|c|}
\hline 3. & $\begin{array}{l}\text { Baptiste et al. } \\
2010\end{array}$ & $\begin{array}{l}\text { Nigeria } \\
\text { (Jun } \\
2006- \\
\text { Feb } \\
2007 \text { ) }\end{array}$ & $\begin{array}{l}\text { Women } \\
\text { and men in } \\
\text { northern } \\
\text { Nigeria: } \\
\text { Kaduna } \\
\text { and Kano } \\
\text { States }\end{array}$ & $\begin{array}{l}\text { Non- } \\
\text { listeners } \\
\text { to radio } \\
\text { drama }\end{array}$ & $\begin{array}{l}\text { 70-episode, } \\
\text { research-based } \\
\text { radio serial drama } \\
\text { called Gugar Goge } \\
\text { (Tell it to me } \\
\text { Straight), depicting } \\
\text { the life of a 12- } \\
\text { year-old girl with } \\
\text { OF; broadcast over } \\
\text { radio stations; } \\
\text { discusses how } \\
\text { women can access } \\
\text { fistula treatment }\end{array}$ & & Awareness & $\begin{array}{l}92 \% \text { of the } \\
\text { population heard at } \\
\text { least one episode } \\
\text { and } 82 \% \text { reported } \\
\text { listening weekly; } \\
\text { increase in health } \\
\text { care services and } \\
\text { fistula services; 32\% } \\
\text { of male listeners } \\
\text { strongly agreed that } \\
\text { "a woman with fistula } \\
\text { should be part of the } \\
\text { community like } \\
\text { everyone else," } \\
\text { compared with } 18 \% \\
\text { of male non-listeners }\end{array}$ & High \\
\hline 4. & $\begin{array}{l}\text { Fiander \& } \\
\text { Vanneste } \\
2012\end{array}$ & $\begin{array}{l}\text { Tanzania } \\
\text { (1 year) }\end{array}$ & $\begin{array}{l}\text { Patients at } \\
\text { CCBRT for } \\
\text { fistula } \\
\text { repair }\end{array}$ & $\begin{array}{l}\text { Year } \\
\text { before }\end{array}$ & & $\begin{array}{l}\text { CCBRT set up } \\
\text { transportMYpatient } \\
\text { using M-PESA; } \\
\text { CCBRT visited } 4 \\
\text { regions in } 2010 \text { to } \\
\text { spread awareness } \\
\text { about } \\
\text { transportMYpatient }\end{array}$ & $\begin{array}{l}\text { Financial; } \\
\text { Transportation }\end{array}$ & $\begin{array}{l}65 \% \text { increase in the } \\
\text { number of fistula } \\
\text { repairs performed in } \\
2010 \text { compared with } \\
2009\end{array}$ & High \\
\hline 5. & $\begin{array}{l}\text { Fiander et al. } \\
2013\end{array}$ & $\begin{array}{l}\text { Tanzania } \\
(2009- \\
2011)\end{array}$ & $\begin{array}{l}\text { Women } \\
\text { arriving at } \\
\text { CCBRT via } \\
\text { the } \\
\text { transportM } \\
\text { Ypatient } \\
\text { initiative }\end{array}$ & $\begin{array}{l}\text { Pre- } \\
\text { interven } \\
\text { tion }\end{array}$ & & $\begin{array}{l}\text { CCBRT introduced } \\
\text { transportMYpatient } \\
\text { to overcome travel } \\
\text { costs; uses mobile } \\
\text { banking to cover } \\
\text { transport costs for } \\
\text { patients with } \\
\text { fistula; Identifies } \\
\text { women using } \\
\text { ambassador } \\
\text { network }\end{array}$ & Transportation & $\begin{array}{l}\text { Increase in number } \\
\text { of fistula repairs } \\
\text { post-intervention } \\
\text { from } 170 \text { to } 339 \text {. } \\
\text { Transported } 166 \\
\text { patients in } 2011 \text {, } \\
\text { accounting for } 49 \% \\
\text { of total repairs }\end{array}$ & High \\
\hline 6. & $\begin{array}{l}\text { Gerten et al. } \\
2009\end{array}$ & $\begin{array}{l}\text { Nigeria } \\
\text { (Jul } \\
2007 \text { ) }\end{array}$ & $\begin{array}{l}\text { Women } \\
\text { awaiting or } \\
\text { recently } \\
\text { undergone } \\
\text { VVF } \\
\text { surgery }\end{array}$ & None & $\begin{array}{l}\text { Educational } \\
\text { brochure for } \\
\text { patients }\end{array}$ & & Awareness & $\begin{array}{l}\text { Women felt that the } \\
\text { information they } \\
\text { learned from the } \\
\text { brochure was helpful }\end{array}$ & Low \\
\hline
\end{tabular}




\begin{tabular}{|c|c|c|c|c|c|c|c|c|c|}
\hline 7. & $\begin{array}{l}\text { Iliyasu et al. } \\
2007\end{array}$ & $\begin{array}{l}\text { Nigeria } \\
\text { (Feb 21 - } \\
\text { Mar 6, } \\
2005 \text { ) }\end{array}$ & $\begin{array}{l}\text { Women } \\
\text { living with } \\
\text { untreated } \\
\text { fistula in } \\
\text { Kano, } \\
\text { Katsina, } \\
\text { Kebbi, and } \\
\text { Sokoto } \\
\text { states, } \\
\text { Nigeria }\end{array}$ & None & $\begin{array}{l}\text { The media and } \\
\text { traditional and } \\
\text { religious leaders } \\
\text { were engaged to } \\
\text { raise awareness } \\
\text { about fistula and } \\
\text { treatment options }\end{array}$ & $\begin{array}{l}\text { Over } 100 \text { providers } \\
\text { trained in fistula } \\
\text { surgery, post-op } \\
\text { care and } \\
\text { counseling; } 10 \\
\text { doctors, } 40 \text { nurses, } \\
\text { and } 60 \text { social } \\
\text { workers and } \\
\text { volunteers trained } \\
\text { in fistula } \\
\text { management; } \\
\text { infrastructure and } \\
\text { facilities upgraded }\end{array}$ & $\begin{array}{l}\text { Facility } \\
\text { shortages; } \\
\text { Awareness }\end{array}$ & $\begin{array}{l}\text { Over } 1000 \text { women } \\
\text { with fistulas arrived } \\
\text { at the facilities for } \\
\text { treatment; } 564 \\
\text { received care with an } \\
87 \% \text { success rate }\end{array}$ & High \\
\hline 8. & $\begin{array}{l}\text { Marcus et al. } \\
2009\end{array}$ & $\begin{array}{l}\text { Ethiopia } \\
\text { (Jul 2006 } \\
\text { - Sep } \\
2009 \text { ) }\end{array}$ & $\begin{array}{l}\text { Women } \\
\text { with fistula } \\
\text { in the } \\
\text { Amhara } \\
\text { region, } \\
\text { Ethiopia }\end{array}$ & None & $\begin{array}{l}\text { Pre-repair centres } \\
\text { provide medical } \\
\text { care, food, baths, } \\
\text { and clothes; } \\
\text { counseling } \\
\text { regarding fistula, } \\
\text { hygiene, FP, HIV, } \\
\text { and sexual } \\
\text { relations after } \\
\text { surgery } \\
\text { Community } \\
\text { outreach program } \\
\text { with educated } \\
\text { volunteers who } \\
\text { disseminate fistula } \\
\text { information to } \\
\text { people in } \\
\text { churches, } \\
\text { mosques, markets, } \\
\text { schools, and } \\
\text { homes }\end{array}$ & $\begin{array}{l}\text { Fistula pre-repair } \\
\text { centers established } \\
\text { to identify fistula } \\
\text { repair patients, } \\
\text { screen women for } \\
\text { repair, and provide } \\
\text { pre-surgery care; } \\
\text { Transportation to } \\
\text { hospital also } \\
\text { provided }\end{array}$ & $\begin{array}{l}\text { Facility } \\
\text { shortages; } \\
\text { Awareness }\end{array}$ & $\begin{array}{l}811 \text { women } \\
\text { screened at } 3 \text { pre- } \\
\text { repair centres; } 76 \% \\
\text { were referred to the } \\
\text { hospital. } \\
\text { Religious leaders } \\
\text { reached } 200-600 \\
\text { people per day. } \\
\text { From Sep } 2007 \text { to } \\
\text { Oct } 2008 \text {, nearly } \\
1,000 \text { volunteers } \\
\text { reached more than } \\
2,000 \text { people per } \\
\text { month }\end{array}$ & High \\
\hline 9. & $\begin{array}{l}\text { Raassen } \\
2006\end{array}$ & $\begin{array}{l}\text { Tanzania, } \\
\text { Somalia, } \\
\text { Uganda, } \\
\text { \& Kenya } \\
\text { (1 year) }\end{array}$ & $\begin{array}{l}\text { Women } \\
\text { needing } \\
\text { fistula } \\
\text { repair }\end{array}$ & None & & $\begin{array}{l}\text { Flying Doctors } \\
\text { Service providing } \\
\text { VVF-repair at } \\
\text { remote government } \\
\text { \&mission hospitals } \\
\text { in EA; includes } \\
\text { training local Drs. }\end{array}$ & $\begin{array}{l}\text { Facility } \\
\text { Shortages }\end{array}$ & $\begin{array}{l}\text { In } 2004 \text { over } 1300 \\
\text { VVF/RVF repairs } \\
\text { performed in Eastern } \\
\text { Africa by AMREF; } \\
\text { increase in number } \\
\text { of hospitals offering } \\
\text { fistula repairs }\end{array}$ & High \\
\hline
\end{tabular}




\begin{tabular}{|c|c|c|c|c|c|c|c|c|c|}
\hline & \begin{tabular}{|l} 
Ramsey et al. \\
2007
\end{tabular} & $\begin{array}{l}\text { Nigeria } \\
\text { (Feb 21 - } \\
\text { Mar 6, } \\
\text { 2005) }\end{array}$ & $\begin{array}{l}\text { Women } \\
\text { arriving for } \\
\text { fistula } \\
\text { repair at } 4 \\
\text { repair } \\
\text { centers } \\
\text { during } \\
\text { fistula } \\
\text { fortnight }\end{array}$ & None & $\begin{array}{l}\text { Fistula Fortnight: } \\
\text { Included patient } \\
\text { recruitment, } \\
\text { mobilization of } \\
\text { traditional and } \\
\text { political leaders, } \\
\text { and awareness- } \\
\text { raising among the } \\
\text { general population }\end{array}$ & $\begin{array}{l}\text { Renovations to } \\
\text { established repair } \\
\text { centers in northern } \\
\text { Nigeria; provision of } \\
\text { equipment and } \\
\text { supplies; training of } \\
\text { providers; flying in } \\
\text { international } \\
\text { surgeons }\end{array}$ & $\begin{array}{l}\text { Facility } \\
\text { shortages; } \\
\text { Financial; } \\
\text { Awareness }\end{array}$ & $\begin{array}{l}569 \text { women received } \\
\text { treatment; } 87.8 \% \\
\text { rate of successful } \\
\text { closures; increased } \\
\text { awareness of } \\
\text { obstetric fistula }\end{array}$ & High \\
\hline 10. & \begin{tabular}{|l} 
Sunday- \\
Adeoye \& \\
Landry 2012
\end{tabular} & $\begin{array}{l}\text { Nigeria } \\
\text { (Jun - Jul } \\
2008)\end{array}$ & $\begin{array}{l}\text { Women } \\
\text { potentially } \\
\text { living with } \\
\text { fistula } \\
\text { Ebonyi } \\
\text { State, } \\
\text { Nigeria }\end{array}$ & None & $\begin{array}{l}\text { Radio and } \\
\text { television } \\
\text { messages, and } \\
\text { community } \\
\text { gatherings to } \\
\text { spread the word } \\
\text { about screenings }\end{array}$ & $\begin{array}{l}\text { Fistula screening } \\
\text { services and free } \\
\text { surgery offered }\end{array}$ & $\begin{array}{l}\text { Awareness; } \\
\text { Financial }\end{array}$ & $\begin{array}{l}\text { Identified backlog } \\
\text { but many women did } \\
\text { not attend initial } \\
\text { screening. Many } \\
\text { more women needed } \\
\text { services than were } \\
\text { originally identified, } \\
\text { and suggesting that } \\
\text { more may yet need } \\
\text { to be identified }\end{array}$ & Medium \\
\hline 11. & USAID 2010 & $\begin{array}{l}\text { Nigeria } \\
\text { (Oct } 2006 \\
- \text { Jul } \\
2010)\end{array}$ & $\begin{array}{l}\text { Women in } \\
\text { northern } \\
\text { Nigeria } \\
\text { waiting for } \\
\text { treatment } \\
\text { at facilities } \\
\text { offering } \\
\text { fistula } \\
\text { repair }\end{array}$ & None & & $\begin{array}{l}\text { Formation of a } \\
\text { clinical peer- } \\
\text { support network } \\
\text { and } 28 \text { pooled } \\
\text { effort events (5-7 } \\
\text { days), in which host } \\
\text { repair facilities } \\
\text { invite } 3-5 \text { surgeons } \\
\text { from other facilities } \\
\text { to work together for } \\
\text { a time period }\end{array}$ & $\begin{array}{l}\text { Facility } \\
\text { shortages }\end{array}$ & $\begin{array}{l}958(19 \%) \text { repairs } \\
\text { during events; 5,111 } \\
\text { total number of } \\
\text { repairs in total }\end{array}$ & Medium \\
\hline 12. & $\begin{array}{l}\text { USAID/ } \\
\text { ACQUIRE } \\
2007\end{array}$ & $\begin{array}{l}\text { Ethiopia } \\
\text { (Jan } \\
2006 \text { - } \\
\text { Mar } \\
2007 \text { ) }\end{array}$ & $\begin{array}{l}\text { Women } \\
\text { living with } \\
\text { fistula in } \\
\text { Ethiopia } \\
\text { and health } \\
\text { care } \\
\text { providers }\end{array}$ & $\begin{array}{l}\text { Pre- } \\
\text { interven } \\
\text { tion }\end{array}$ & $\begin{array}{l}\text { Community } \\
\text { sensitization } \\
\text { activities to } \\
\text { increase } \\
\text { awareness of } \\
\text { fistula }\end{array}$ & $\begin{array}{l}\text { Improving capacity } \\
\text { to deliver fistula } \\
\text { screening and care, } \\
\text { at } 18 \text { facilities; } \\
\text { preparing health } \\
\text { workers and TBAs } \\
\text { to refer women with } \\
\text { fistula; improving } \\
\text { referral system; } \\
\text { providing supplies/ } \\
\text { equipment }\end{array}$ & $\begin{array}{l}\text { Awareness; } \\
\text { Quality of } \\
\text { Care; Facility } \\
\text { Shortages }\end{array}$ & $\begin{array}{l}461 \text { women were } \\
\text { screened for fistula } \\
\text { and } 236 \text { were } \\
\text { diagnosed; } 172 \text { were } \\
\text { cured. } \\
3 \text { pre-repair centers } \\
\text { established } \\
\text { Provider Training }\end{array}$ & Medium \\
\hline
\end{tabular}


